\title{
Impact of ocean acidification on thermal tolerance and acid-base regulation of Mytilus edulis (L.) from the North Sea
}

\author{
Zora M.C. Zittier* , Christian Bock, Gisela Lannig, Hans O. Pörtner \\ Integrative Ecophysiology, Alfred Wegener Institute Helmholtz Centre for Polar and Marine Research, Am Handelshafen 12, D-27570 Bremerhaven, Germany
}

\section{A R T I C L E I N F O}

\section{Article history:}

Received 24 March 2015

Received in revised form 31 July 2015

Accepted 1 August 2015

Available online $\mathrm{xxxx}$

\section{Keywords:}

Warming

Oxygen consumption

Heart rate

Succinate

Extracellular $\mathrm{pH}$

NMR spectroscopy

\begin{abstract}
A B S T R A C T
Anthropogenic climate change confronts marine organisms with rapid trends of concomitant warming and $\mathrm{CO}_{2}$ induced ocean acidification. The survival and distribution of species partly depend on their ability to exploit their physiological plasticity during acclimatization. Therefore, in laboratory studies the effects of simulated future ocean acidification on thermal tolerance, energy metabolism and acid-base regulation capacity of the North Sea population of the blue mussel Mytilus edulis were examined. Following one month of pre-acclimation to $10{ }^{\circ} \mathrm{C}$ and control $\mathrm{CO}_{2}$ levels, mussels were exposed for two weeks to control and projected oceanic $\mathrm{CO}_{2}$ levels (390, 750 and $1120 \mu \mathrm{atm}$ ) before being subjected to a stepwise warming protocol between $10{ }^{\circ} \mathrm{C}$ and $31{ }^{\circ} \mathrm{C}$ $\left(+3{ }^{\circ} \mathrm{C}\right.$ each night). Oxygen consumption and heart rates, anaerobic metabolite levels and haemolymph acidbase status were determined at each temperature. $\mathrm{CO}_{2}$ exposure left oxygen consumption rate unchanged at acclimation temperature but caused a somewhat stronger increase during acute warming and thus mildly higher $\mathrm{Q}_{10^{-}}$-values than seen in controls. Interestingly, the thermally induced limitation of oxygen consumption rate set in earlier in normocapnic than in hypercapnic $\left(1120 \mu \mathrm{atm} \mathrm{CO}_{2}\right)$ mussels $\left(25.2^{\circ} \mathrm{C}\right.$ vs. $\left.28.8^{\circ} \mathrm{C}\right)$, likely due to an onset of metabolic depression in the control group following warming. However, the temperature induced increase in heart rate became limited above $25^{\circ} \mathrm{C}$ in both groups indicating an unchanged pejus temperature regardless of $\mathrm{CO}_{2}$ treatment. An upper critical temperature was reached above $28^{\circ} \mathrm{C}$ in both treatments indicated by the accumulation of anaerobic metabolites in the mantle tissue, paralleled by a strong increase in haemolymph $\mathrm{PCO}_{2}$ at $31^{\circ} \mathrm{C}$. Ocean acidification caused a decrease in haemolymph pH. The extracellular acidosis remained largely uncompensated despite some bicarbonate accumulation. In all treatments animals developed a progressive warming-induced extracellular acidosis. A stronger $\mathrm{pH}$ drop at around $25^{\circ} \mathrm{C}$ was followed by stagnating heart rates. However, normocapnic mussels enhanced bicarbonate accumulation at the critical limit, a strategy no longer available to hypercapnic mussels. In conclusion, $\mathrm{CO}_{2}$ has small effects on the response patterns of mussels to warming, leaving thermal thresholds largely unaffected. High resilience of adult North Sea mussels to future ocean acidification indicates that sensitivity to thermal stress is more relevant in shaping the response to future climate change.
\end{abstract}

(c) 2015 Elsevier B.V. All rights reserved.

\section{Introduction}

Coastal regions host a variety of ecosystems that are increasingly threatened by anthropogenic climate change. Current climate change confronts marine organisms with multiple stressors such as increasing temperature, $\mathrm{CO}_{2}$ and hypoxia (Pörtner et al., 2014). Temperature is the main factor shaping the performance of marine animals as it affects organisms in all life-stages and at all levels of biological organisation. There is evidence that temperature-induced impacts on marine

\footnotetext{
* Corresponding author at: Alfred Wegener Institute, Am Handelshafen 12, D-27570 Bremerhaven, Germany.

E-mail addresses:Zora.Zittier@awi.de (Z.M.C.Zittier), Christian.Bock@awi.de (C. Bock), Gisela.Lannig@awi.de (G. Lannig), Hans.Poertner@awi.de (H.O. Pörtner).
}

ectothermic animals are based on unifying principles of physiological response, which led to the concept of oxygen- and capacity-limited thermal tolerance (OCLTT; for review, see Pörtner, 2010). This concept links physiological principles of thermal tolerance to climate-driven ecosystem changes. According to the OCLTT concept, the oxygen supply of an organism is maximal in the optimum temperature range $\left(T_{O}\right)$ between upper and lower pejus thresholds, with performance being maximal close to upper pejus limits. This range characterizes the ecological thermal tolerance range where availability of aerobic energy is maximal for all physiological functions including growth, development and reproduction and therefore determines the geographical distribution of species and populations. In temperate zone species surpassing either an upper or lower pejus temperature $\left(T_{\mathrm{P}}\right)$ leads to a mismatch between oxygen uptake and demand as circulation and/or ventilation reach their capacity limits resulting in internal hypoxemia of the organism and thus 
progressively reduced aerobic performance and whole animal fitness, visible in a reduction of growth, reproduction etc. The next thresholds are the critical temperatures $\left(\mathrm{T}_{\mathrm{C}}\right)$ when oxygen supply to tissues becomes insufficient to maintain energy expenditure resulting in a transition to anaerobic energy metabolism.

While temperature is the main factor driving current ecosystem changes (Poloczanska et al., 2014), impacts of increasing $\mathrm{CO}_{2}$ concentrations (causing ocean acidification, i.e. reductions in seawater $\mathrm{pH}$, carbonate levels and carbonate saturation values) are expected to become increasingly involved, especially in upwelling areas (e.g. Barton et al., 2012). Future ocean acidification has the potential to disturb life-sustaining processes in marine organisms like growth, reproduction, energy metabolism and acid-base regulation. Especially calcifying organisms, like bivalves, are projected to be adversely affected due to the additional challenges involved in forming and protecting their calcareous shells and skeletons under the altered seawater carbonate chemistry (Fabry et al., 2008; Doney et al., 2009; Kroeker et al., 2010). Furthermore, the capacity for acid-base regulation is crucial for the scope of whole animal performance (Pörtner, 2008), but, in contrast to fish and crustaceans, bivalves and echinoderms are regarded to be weak acid-base regulators (for review, see Melzner et al., 2009; Parker et al., 2013). These circumstances gain increasing attention as several calcifiers are important species in costal ecosystem functioning and moreover for shellfish economies. In case of the North Sea, beds of Mytilus edulis provide substratum for various epibionts and offer shelter and food for a diverse community of organisms. A glimpse into the future is provided by massive die-offs of shellfish larvae due to shifts towards high- $\mathrm{CO}_{2}$ upwelling conditions over the last years in coastal regions of the northeast Pacific Ocean (Barton et al., 2012).

One main strategy of marine invertebrates to survive short periods of elevated $\mathrm{CO}_{2}$ exposure passively is the so-called metabolic depression with an associated reduction in ventilation (Guppy et al., 1994; Langenbuch and Pörtner, 2002; Michaelidis et al., 2005). However, this strategy may result harmful in the long term. Michaelidis et al. (2005) found permanently depressed aerobic metabolism in Mytilus galloprovincialis over $90 \mathrm{~d}$ of severe hypercapnia at $\sim 5000 \mu$ atm leading to a $50 \%$ reduction in growth rate. Over a similar time period moderate hypercapnia of $\sim 2000 \mu$ atm caused a significant reduction of oxygen consumption, clearance and ingestion rates in clams Ruditapes decussatus (Fernández-Reiriz et al., 2011). Further studies found no effect of $\mathrm{CO}_{2}$ levels projected by $2100(\leq 2000 \mu \mathrm{atm})$ on oxygen consumption rates of bivalves (Lannig et al., 2010; Fernández-Reiriz et al., 2012; Liu and He, 2012; Schalkhausser et al., 2012). In M. edulis from the Baltic (Kiel Fjord) no reduction in oxygen consumption was found even at $2500 \mu \mathrm{atm}$ (Thomsen and Melzner, 2010). However, elevated background $\mathrm{CO}_{2}$ levels in the fjord indicate that this population may be pre-adapted such that $\mathrm{CO}_{2}$ levels applied during experimental exposures were not high enough to elicit the respective response. This preadaptation might not exist in populations from habitats with $\mathrm{CO}_{2}$ levels similar to the atmosphere.

Recently, it could be shown that acute warming combined with hypercapnia exacerbates the warming induced constraints on aerobic energy metabolism and performance of decapod crustaceans (Metzger et al., 2007; Walther et al., 2009; Zittier et al., 2013). Hypercapnia caused a narrowing of the thermal window due to a downward shift of the upper critical temperature (Metzger et al., 2007; Walther et al., 2009).

The aim of the present study was to test a potential net effect of hypercapnia on thermal tolerance and acid-base regulation capacity of a commercially important marine bivalve, the blue mussel $M$. edulis from the North Sea. The impact of realistic $\mathrm{CO}_{2}$ scenarios for two weeks was investigated before animals were exposed to acute warming. Oxygen consumption, heart rate, anaerobic metabolite accumulation in mantle tissue and acid-base status of haemolymph and extrapallial fluid were measured to elucidate the combined effects of the two drivers on performance.

\section{Material \& methods}

\subsection{Animal collection and maintenance}

Wild type adult mussels, M. edulis (50 to $90 \mathrm{~mm}$ shell length) were collected from the subtidal zone around Helgoland, German Bight in June 2009 after the main larval peak. Seawater $\mathrm{CO}_{2}$ levels of this area are relatively stable throughout the year and similar to atmospheric levels (average $\leq 400 \mu \mathrm{atm}$ ) (e.g. Thomas et al., 2007). Mussels were transported in tanks that were constantly flooded with North Sea water to the Alfred-Wegener-Institute for Polar and Marine Research (AWI, Bremerhaven, Germany) within $24 \mathrm{~h}$ after collection by the research vessel Uthörn. Mussels were separated, cleaned from epibionts and maintained in aerated and filtered natural seawater from the North Sea at $10{ }^{\circ} \mathrm{C}$ and a salinity of 32 in the aquarium facility of the AWI. Following pre-acclimation for at least one month, mussels were randomly placed in one of four tanks per group (15 L, max. 18 animals) and incubated for 2 weeks under different $\mathrm{CO}_{2}$ concentrations (see below). Mussels were fed daily ad libitum with freshly hatched Artemia larvae (as suitable diet, e.g. Davenport et al., 2000) and a commercial living algal blend containing Nannochloropsis, Phaeodactylum tricornutum and Chlorella (DT's Live Marine Phytoplankton, Coralsands, Germany). To avoid interference with postprandial metabolism (e.g. Bayne and Scullard, 1977; Gaffney and Diehl, 1986) feeding was terminated three days before experimentation. All animal tanks (acclimation, incubation and experimental tanks) were cleaned daily from faeces and pseudofaeces.

\subsection{Incubation and experimental set up}

For $\mathrm{CO}_{2}$ incubations, systems were set up in a temperature control room $\left(10{ }^{\circ} \mathrm{C}\right)$ using several reservoirs $(450 \mathrm{~L})$ and header tanks $(210 \mathrm{~L})$ to provide different treatment conditions according to projected scenarios of oceanic $\mathrm{CO}_{2}$ levels (today: 390 and towards the year 2100: 750 and $1120 \mu \mathrm{atm}$ ). Water was circulated between the reservoir and the header tank; both were continuously bubbled with the respective air- $\mathrm{CO}_{2}$ mixture via a HTK gas system (Hamburg, Germany). From the header tank, water was supplied to the animal tanks $(15 \mathrm{~L})$ at a flow rate of $\sim 120 \mathrm{~mL} \mathrm{~min}{ }^{-1}$, thereby providing stable $\mathrm{CO}_{2}$ conditions. It was then collected in a $210 \mathrm{~L}$ basin re-equilibrated by continuous bubbling and re-circulated to the reservoir. Water was exchanged two times a week after disconnecting the reservoir from the system. Subsequently, the system was refilled and equilibrated for $24 \mathrm{~h}$ while the water from the basin was re-circulated into the header tank.

The experimental setup comprised two animal tanks ( $80 \mathrm{~L}$, starting with 36 animals) and a reservoir (for water exchange), all temperatures were feedback-controlled by a thermostat (LAUDA RP 845, LaudaKönigshofen) and continuously bubbled with the respective air- $\mathrm{CO}_{2}$ mixture produced by a MKS mass flow controller (MKS Instruments Deutschland $\mathrm{GmbH}$, München). Each animal tank contained four respiration chambers. Water was exchanged before each temperature rise.

Temperature $(\mathrm{T})$, salinity $(\mathrm{S}), \mathrm{pH}$, and total alkalinity $(\mathrm{TA})$ were measured daily in all animal tanks (incubation, experimental and reservoirs tanks for water changes) for determining the water chemistry. Measurements were carried out using a salinometer (WTW LF197 combination temperature and salinity probe) and a pH meter (NBS scale, Mettler-Toledo $\mathrm{pH}$ meter). TA was analysed by potentiometric titration (METROHM Prozessanalytik GmbH\&Co, Germany). The partial pressure of $\mathrm{CO}_{2}$ in seawater $\left(\mathrm{PCO}_{2}\right)$ was calculated based on the measured parameters using the CO2SYS program (Pierrot et al., 2006) after equilibrium constants of Mehrbach et al. (1973) for the $\mathrm{CO}_{2}$ /bicarbonate/ carbonate system, as refitted by Dickson and Millero (1987) and used for $\mathrm{KSO}_{4}$ as provided by Dickson (1990) (incubation: Table 1, experimentation: Table 2). 
Table 1

Carbonate chemistry of seawater during the incubation of blue mussels, $M$. edulis at different $\mathrm{CO}_{2}$ concentrations.

\begin{tabular}{lllrr}
\hline $\mathrm{PCO}_{2} \mu \mathrm{atm}(\mathrm{set})$ & $\mathrm{T}{ }^{\circ} \mathrm{C}(\mathrm{set})$ & \multicolumn{1}{l}{$\mathrm{pH}_{\mathrm{NBS}}$} & $\mathrm{PCO}_{2} \mu \mathrm{atm}$ & \multicolumn{1}{c}{${ }^{\circ} \mathrm{C}$} \\
\hline 390 & 10 & $8.14 \pm 0.03$ & $443 \pm 30$ & $10.1 \pm 0.5$ \\
750 & 10 & $7.91 \pm 0.02$ & $758 \pm 74$ & $10.1 \pm 0.5$ \\
1120 & 10 & $7.81 \pm 0.02$ & $1037 \pm 93$ & $9.7 \pm 0.1$ \\
\hline
\end{tabular}

\subsection{Preparation of animals and experimental protocol}

After $\mathrm{CO}_{2}$-exposure mussels were transferred into the experimental setup. Eight mussels per treatment $(\mathrm{N}=72)$ were used for parallel measurements of oxygen consumption and heart rate. Shell thickness was reduced by grinding and a plethysmograph infrared sensor (Vishay Semiconductors, CNY70) was placed above the pericardial cavity for non-invasive heart rate measurements. The sensors were integrated through the lid of the respiration chamber, superglued to the shell and covered with dental wax. Mussels were then placed into respiration chambers within the experimental tanks. In order to monitor recovery from handling stress recordings of oxygen consumption and heart rate were started immediately. After stable reading was obtained (after 3 to $7 \mathrm{~h}$ depending on individual; see Fig. 1) data were collected for analyses. Other mussels of the respective treatment (for the sampling of tissues and body fluids) were left undisturbed at least overnight after being transferred to the experimental tanks.

Measurements were started at control temperature $\left(10^{\circ} \mathrm{C}\right)$ and temperature was increased by $3^{\circ} \mathrm{C}$ every night. Temperature was increased up to $22{ }^{\circ} \mathrm{C}$ ( $=1$ st run) under all $\mathrm{CO}_{2}$ conditions $(390,750,1120 \mu \mathrm{atm}$; all data shown). As data analyses revealed that individuals did not reach their critical temperatures, a 2 nd run up to $31{ }^{\circ} \mathrm{C}$ was carried out two months later under control ( $390 \mu \mathrm{atm})$ and high $\mathrm{CO}_{2}$ conditions (1120 $\mu a t m)$. These data are displayed for the temperature interval from $25{ }^{\circ} \mathrm{C}$ to $31^{\circ} \mathrm{C}$. Mussels used in the 2 nd run were treated in the same way (incubation time, feeding procedure, handling, etc.) and displayed similar size and weight ranges when compared to the 1 st run. Occasional measurements of all parameters were performed below $25{ }^{\circ} \mathrm{C}$ during the 2 nd run and confirmed the comparability of both data sets.

Mussels were kept unfed during the whole temperature trial to avoid postprandial rise in metabolism. Reduced food amount can modulate the stress sensitivity of animals - especially during long-term experiments (Melzner et al., 2011) but pre-experiments performed over one week at constant temperature $\left(10^{\circ} \mathrm{C}\right)$ under the respective $\mathrm{CO}_{2}$ levels did not reveal temporal variation indicating that animals of the present study were post-absorptive but not yet depressing metabolism due to starvation. That the lack of food might induce an adverse effect when high temperatures are reached is questionable as food induced metabolism will also cause a lowering of thermal limits. However, all

\section{Table 2}

Carbonate chemistry of seawater during the experimentation with blue mussels, $M$. edulis (acute warming protocol, $3{ }^{\circ} \mathrm{C} /$ night) at different $\mathrm{CO}_{2}$ concentrations $(390,750,1120$ $\mu \mathrm{atm})$. Total alkalinity was very stable throughout the experimental period with $2411 \pm$ $17,2414 \pm 10$ and $2412 \pm 27 \mu \mathrm{atm} / \mathrm{kg} \mathrm{SW}$, respectively.

\begin{tabular}{|c|c|c|c|c|c|c|c|c|c|}
\hline \multirow[t]{2}{*}{$\mathrm{T}^{\circ} \mathrm{C}$ (set) } & \multicolumn{3}{|c|}{$390 \mu \mathrm{atm}$} & \multicolumn{3}{|c|}{$750 \mu \mathrm{atm}$} & \multicolumn{3}{|c|}{$1120 \mu \mathrm{atm}$} \\
\hline & $\mathrm{T}^{\circ} \mathrm{C}$ & $\mathrm{pH}_{\mathrm{NBS}}$ & $\begin{array}{l}P_{2} \\
\mu a t m\end{array}$ & $\mathrm{~T}^{\circ} \mathrm{C}$ & $\mathrm{pH}_{\mathrm{NBS}}$ & $\begin{array}{l}\mathrm{PCO}_{2} \\
\mu \text { atm }\end{array}$ & $\mathrm{T}^{\circ} \mathrm{C}$ & $\mathrm{pH}_{\mathrm{NBS}}$ & $\begin{array}{l}P_{2} \\
\mu a t m\end{array}$ \\
\hline 10 & 10.1 & 8.35 & 344.8 & 10.1 & 7.94 & 752.2 & 10.3 & 7.76 & 1202.9 \\
\hline 13 & 12.8 & 8.20 & 410.4 & 13.1 & 7.94 & 850.0 & 13.2 & 7.79 & 1124.9 \\
\hline 16 & 16.3 & 8.19 & 406.8 & 16.0 & 7.95 & 770.0 & 16.4 & 7.84 & 1020.4 \\
\hline 19 & 18.9 & 8.20 & 412.6 & 18.7 & 7.99 & 723.1 & 19.2 & 7.83 & 1082.3 \\
\hline 22 & 22.0 & 8.15 & 487.5 & 22.3 & 7.97 & 868.6 & 21.9 & 7.85 & 1063.0 \\
\hline 25 & 24.9 & 8.05 & 600.6 & & & & 24.9 & 7.76 & 1195.9 \\
\hline 28 & 27.8 & 8.11 & 496.1 & & & & 27.8 & 7.75 & 1410.4 \\
\hline 31 & 30.9 & 8.09 & 527.8 & & & & 31.1 & 7.80 & 1170.8 \\
\hline
\end{tabular}

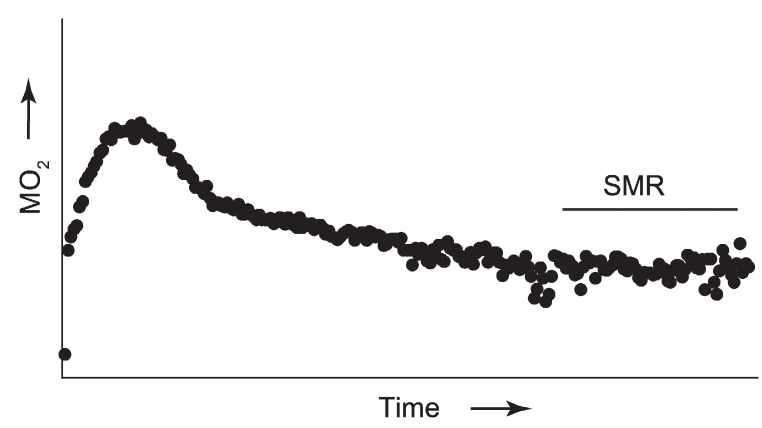

Fig. 1. Example of oxygen consumption $\left(\mathrm{MO}_{2}\right)$ pattern of individual Mytilus edulis over time after preparation for experimental analyses. The initial $\mathrm{MO}_{2}$ increase reflects the time span the system needs to equilibrate. The adjacent stabilized phase indicates metabolic rate elevation after handling stress. The subsequent decrease in $\mathrm{MO}_{2}$ reflects the recovery phase and return to SMR (standard metabolic rate). SMR was reached after 3 to $7 \mathrm{~h}$ depending on the individual and the time span until first valve opening occurred after handling.

animals were treated in the same way making the data of normocapnic and hypercapnic animals comparable and differences in the response can, thus, be attributed to the $\mathrm{CO}_{2}$ levels applied. Moreover, all mussels were in good shape also at the end of the 2nd run, as confirmed by condition indices $(\mathrm{Cl}$, calculated as: dry meat weight $[\mathrm{g}] \times 1000 /$ (shell length $[\mathrm{cm}])^{3}$ ) of $4.96 \pm 1.03$ at $390 \mu$ atm and $4.67 \pm 0.91$ at $1120 \mu \mathrm{atm}$ that lay well in the range of previously findings for M. edulis (cf. Lundebye et al., 1997).

Oxygen consumption and heart rates were recorded online throughout the experimental period. Data from the first $5 \mathrm{~h}$ after temperature rise were discarded to disregard short-term acclimation. In addition, samples of body fluids and tissue were collected at each temperature $(\mathrm{N}=6-8)$ from parallel incubations of non-monitored mussels. Samples of body fluids (haemolymph and extrapallial fluid) were removed with gas-tight sterile syringes. Haemolymph was withdrawn from the posterior adductor muscle and extrapallial fluid was sampled with a long $(8 \mathrm{~cm})$ needle gently inserted between the shell and the pallial attachment of the mantle. To avoid contact with the atmosphere, both fluids were immediately analysed for acid-base parameters and gas concentrations (see below). Afterwards, the mantle tissue was excised, freeze-clamped and stored in liquid nitrogen until analysis of anaerobic metabolites.

\subsection{Determination of oxygen consumption and heart rate}

Oxygen consumption $\left(\mathrm{MO}_{2}\right)$ measurements were conducted following Van Dijk et al. (1999) using flow-through respirometry. Briefly, the flow rate (3-46 $\mathrm{mL} \mathrm{min}^{-1}$ ) was set in a way that mussels consumed less than $20 \%$ of the $\mathrm{O}_{2}$ from the water. Throughout the experiment only readings of lowest metabolic rates, stable for at least $40 \mathrm{~min}$ (standard metabolic rate, SMR, see Fig. 1) were used for analyses. After the experiment, mussels were dissected to determine shell-free dry weight (DW). $\mathrm{MO}_{2}$ was measured using oxygen optodes with integrated temperature compensation (TX-3, PreSens $\mathrm{GmbH}$, Regensburg). Optodes were calibrated in oxygen-free $\left(0 \%, \mathrm{~N}_{2}\right.$ bubbled) and air-saturated (100\%) seawater. The $100 \%$-oxygen values were checked daily to compensate for temperature and hardware drifts. Once air saturation values deviated from calibrations by more than $2 \%$, recorded data were corrected and a new two-point calibration was performed. Values given as \% air saturation were converted to

$\mathrm{PO}_{2}(\mathrm{kPa})=\left(\mathrm{Patm}-\mathrm{PH} \mathrm{H}_{2} \mathrm{O}\right) \times 0.2095 \times(\%$ air saturation $) / 100$,

where Patm is the atmospheric pressure $(\mathrm{kPa}), \mathrm{PH}_{2} \mathrm{O}$ is the temperature-specific water vapour pressure $(\mathrm{kPa})$, calculated after 
Dejours (1975), and 0.2095 is the fraction of oxygen in air. $\mathrm{MO}_{2}$ was calculated as follows:

$\mathrm{MO}_{2}\left(\mu \mathrm{mol} \mathrm{O} \mathrm{h}^{-1} \mathrm{gDW}^{-1}\right)=\left(\Delta \mathrm{PO}_{2} \times \beta \mathrm{O}_{2} \times \mathrm{V}_{\mathrm{fl}}\right) / \mathrm{DW}$

where $\triangle P \mathrm{O}_{2}$ is the difference in oxygen partial pressure between inflowing and outflowing water $(\mathrm{kPa}), \mathrm{BO}_{2}$ is the temperature-specific oxygen capacity of water $\left(\mu \mathrm{mol} \mathrm{O} \mathrm{O}_{2}^{-1} \mathrm{kPa}^{-1}\right), \mathrm{V}_{\mathrm{fl}}$ is the flow rate $\left(\mathrm{L} \mathrm{h}^{-1}\right)$ and DW is the shell-free dry weight $(\mathrm{g})$ of the mussel. Heart rate was recorded using a PowerLab system with Chart v4.1.1 Software (AD Instruments, Spechbach, Germany). Averaged heart rate was determined at each temperature by counting the peaks expressed as beats per minute (bpm) over 30-90 s intervals within a $3 \mathrm{~h}$ period. Unfortunately, some heart recordings became unreliable at high temperatures possibly due to grounding problems, reducing the available sample size above $22{ }^{\circ} \mathrm{C}$.

\subsection{Determination of gas and acid-base status in haemolymph and extrapallial fluid}

Haemolymph and extrapallial fluid were analysed immediately after sampling. $\mathrm{PO}_{2}, \mathrm{PCO}_{2}$ and $\mathrm{pH}$ were measured using a blood gas analyser (MT 33, Eschweiler, Germany) calibrated at the specific experimental temperature. Total $\mathrm{CO}_{2}$ concentration $\left(\mathrm{CCO}_{2}\right.$, Table 3$)$ of body fluids was determined by gas chromatography (Agilent 6890N GC System, Agilent Technologies, USA). Bicarbonate concentrations ( $\left[\mathrm{HCO}_{3}^{-}\right]$) were calculated from measured $\mathrm{CCO}_{2}(\mathrm{mM})$ and $\mathrm{PCO}_{2}$ (Torr) as follows:

$\left[\mathrm{HCO}_{3}{ }^{-}\right](\mathrm{mM})=\mathrm{CCO}_{2}-\left(\alpha \mathrm{CO}_{2} \times \mathrm{PCO}_{2}\right)$,

where $\alpha \mathrm{CO}_{2}$ is the solubility of $\mathrm{CO}_{2}$ in the body fluid (mM Torr ${ }^{-1}$ ) calculated after Heisler (1986).

\subsection{Tissue extraction and determination of metabolites}

Tissue succinate concentrations were determined as follows. Mantle tissue was powdered under liquid nitrogen using a mortar and pestle. Tissue powder ( $\sim 300 \mathrm{mg})$ was homogenized $\left(0{ }^{\circ} \mathrm{C}, 360 \mathrm{~W}\right)$ with icecold $0.6 \mathrm{M}$ perchloric acid (PCA) added to a vol/wt ratio of 1 to 5 . Precipitated protein was removed by centrifugation $\left(0{ }^{\circ} \mathrm{C}, 2 \mathrm{~min}\right.$ at $\left.16,000 \mathrm{~g}\right)$. The extract was neutralized to a $\mathrm{pH}$ of $\sim 7.5$ with $5 \mathrm{M}$ potassium hydroxide $(\mathrm{KOH})$ and centrifuged again to remove precipitated potassium perchlorate. The supernatant was stored at $-80^{\circ} \mathrm{C}$ until further analysis. Samples were dried in a SpeedVac for ${ }^{1} \mathrm{H}$ NMR spectroscopy. Prior to measurements dried extracts were resolved in $500 \mu \mathrm{L} \mathrm{D} \mathrm{D}_{2} \mathrm{O}$ containing $1 \%$ trimethylsilyl propionate (TSP) as internal reference and transferred to $5 \mathrm{~mm}$ NMR tubes, resulting in a final concentration of $0.3 \mathrm{~g}$ initial tissue powder per mL. Fully relaxed high-resolution ${ }^{1} \mathrm{H}$ NMR spectra were recorded using an inverse ${ }^{1} \mathrm{H}$-broad band probe $\left({ }^{1} \mathrm{H} / \mathrm{BBI}\right)$ on a $400 \mathrm{MHz}$ 9.4 T WB NMR spectrometer with Avance electronics (Bruker Biospin GmbH, Germany) similar to Lannig et al. (2010). Acquisition parameters

Table 3

Total carbon dioxide of haemolymph $\left(\mathrm{CCO}_{2}\right)$ in control (390 $\left.\mu \mathrm{atm}\right)$ and $\mathrm{CO}_{2}$ exposed $(750$ and $1120 \mu \mathrm{atm})$ blue mussels, $M$. edulis during acute warming $\left(3^{\circ} \mathrm{C} / \mathrm{night}\right)$.

\begin{tabular}{llll}
\hline $\mathrm{T}{ }^{\circ} \mathrm{C}$ & \multicolumn{2}{l}{$\mathrm{CCO}_{2}[\mathrm{mM}]$ at given $\mathrm{CO}_{2}$ level } \\
\cline { 2 - 4 } & $390 \mu \mathrm{atm}$ & $750 \mu \mathrm{atm}$ & $1120 \mu \mathrm{atm}$ \\
\hline 10 & $1.53 \pm 0.19$ & $1.83 \pm 0.23$ & $2.36 \pm 0.06$ \\
13 & $1.47 \pm 0.15$ & $1.58 \pm 0.36$ & $1.82 \pm 0.21$ \\
16 & $1.49 \pm 0.12$ & $1.57 \pm 0.14$ & $1.76 \pm 0.11$ \\
19 & $1.55 \pm 0.24$ & $1.50 \pm 0.22$ & $1.62 \pm 0.06$ \\
22 & $1.81 \pm 0.21$ & $1.77 \pm 0.26$ & $1.73 \pm 0.28$ \\
25 & $1.69 \pm 0.16$ & & $1.78 \pm 0.15$ \\
28 & $1.79 \pm 0.16$ & & $2.03 \pm 0.17$ \\
31 & $4.05 \pm 1.20$ & & $2.51 \pm 0.47$ \\
\hline
\end{tabular}

were as follows: $\mathrm{TD}=16 \mathrm{k}, \mathrm{NS}=128, \mathrm{DS}=2, \mathrm{SW}=4.8 \mathrm{k}, \mathrm{AQ}=1.7 \mathrm{~s}$, D1 $=12 \mathrm{~s}$ with a constant receiver gain of RG 203 to ensure comparability of samples. Spectra were post-processed automatically using TopSpin 2.5 (Bruker Biospin GmbH, Germany). All data were zero filled to $64 \mathrm{k}$ and processed with an exponential multiplication of $0.5 \mathrm{~Hz}$ prior to Fourier transformation. After phase and baseline correction, spectra were calibrated to TSP at $0.0 \mathrm{ppm}$. Succinate concentrations were determined by analysing the area under a singlet peak at $2.4 \mathrm{ppm}$, corresponding to the chemical shift of succinate at $\mathrm{pH} 7.5$, using the integration routine in TopSpin.

\subsection{Statistical analysis}

Before data were processed with $\mathrm{R}$ outliers were removed by using Nalimov's test (Noack, 1980). Data were analysed with a ShapiroWilk-Test for normality. Two-way analysis of variance (ANOVA) in combination with Tukey's post hoc test was performed to analyse effects of temperature and $\mathrm{CO}_{2}$ level and possible interactions thereof. Normality was not fulfilled for haemolymph $\mathrm{PO}_{2}$ data, therefore, data were log-transformed prior to analysis. Arrhenius break temperature indicates the discontinuity in the temperature dependence of $\mathrm{MO}_{2}$, at which a significant change in the slope of the plot occurs (Sokal and Rohlf, 1995). However, breakpoint analysis was impossible because a limited number of temperatures resulted above potential breakpoints in the warmth to be able to calculate linear regressions by the leastsquare method (Sokal and Rohlf, 1995). Hence, the phase change was determined using a sigmoidal function that describes the exponential increase of $\mathrm{MO}_{2}$ with rising temperature, and the subsequent limitation in the warmth, when maximum curvature at a value of zero for the second derivate of the model indicates the breakpoint temperature. Differences were considered significant if $\mathrm{P}<0.05$. Values are presented as means $\pm \mathrm{SD}, \mathrm{N}=5-8$ unless stated otherwise.

\section{Results}

Oxygen consumption rates $\left(\mathrm{MO}_{2}\right)$ of $M$. edulis (Fig. 2) were similar under normocapnia (390 $\mu \mathrm{atm}: 7.1 \pm 2.0 \mu \mathrm{mol} \mathrm{O}_{2} \mathrm{~h}^{-1} \mathrm{~g} \mathrm{DW}^{-1}$ ) and hy-

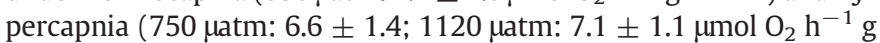
$\left.\mathrm{DW}^{-1}\right)$ at acclimation temperature $\left(10^{\circ} \mathrm{C}\right)$. Warming from 10 to $28^{\circ} \mathrm{C}$ led to a progressive and significant increase in $\mathrm{MO}_{2}$ under both normocapnia and hypercapnia, which resulted in a somewhat higher oxygen consumption rate under elevated $\mathrm{CO}_{2}$ (390 $\mu \mathrm{atm}: 29.2 \pm 11.0$, $\mathrm{P}<0.001, \mathrm{Q} 10=2.19 ; 1120 \mu \mathrm{atm}: 36.8 \pm 5.5 \mu \mathrm{mol} \mathrm{O} \mathrm{h}^{-1} \mathrm{~g} \mathrm{DW}^{-1}$, $\mathrm{P}<0.001 ; \mathrm{Q} 10=2.49)$. After the last temperature rise from $28{ }^{\circ} \mathrm{C}$ to $31{ }^{\circ} \mathrm{C}$ only $43 \%$ ( 3 out of 7 ) of the animals under normocapnia and $63 \%$ ( 5 out of 8 ) under hypercapnia showed a further increase in oxygen consumption rate, while $\mathrm{MO}_{2}$ values in the other animals decreased

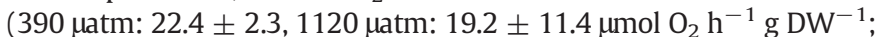
Fig. 2, grey symbols). As calculating a mean from two different responses makes no sense it was focused on animals that can cope with the high temperature and data of decreasing $\mathrm{MO}_{2}$ at $31^{\circ} \mathrm{C}$ were excluded for statistical analyses. Mean values of increased oxygen consumption rates at $31{ }^{\circ} \mathrm{C}(390 \mu \mathrm{atm}: 32.4 \pm 12.7, \mathrm{P}<0.001, \mathrm{~N}=3, \mathrm{Q} 10=$ 2.06; $1120 \mu \mathrm{atm}: 38.4 \pm 8.2 \mu \mathrm{mol} \mathrm{O}_{2} \mathrm{~h}^{-1} \mathrm{~g} \mathrm{DW}^{-1}, \mathrm{P}<0.001, \mathrm{~N}=5$, $\mathrm{Q} 10=2.23$ ) were only slightly higher than those at $28{ }^{\circ} \mathrm{C}$ or even than those at $25^{\circ} \mathrm{C}$ among normocapnic animals. Two-way ANOVA suggested a main effect of temperature $(\mathrm{P}<0.001)$ and $\mathrm{CO}_{2}(\mathrm{P}=0.047)$. The $\mathrm{MO}_{2}$ data were best fitted by a five parameter sigmoidal function revealing that the upper breakpoint temperature (= maximum curvature) was lower under normocapnia $\left(25.19^{\circ} \mathrm{C}\right)$ than under $1120 \mu$ atm $\left(28.84{ }^{\circ} \mathrm{C}\right)$ (Fig. 2, vertical lines).

Samples of tissue and body fluids were collected from nonmonitored mussels (see Section 2.3) with shells open, when selected for sampling. No differences in the succinate levels of mantle tissue were found between the three $\mathrm{CO}_{2}$ conditions throughout the entire experimental period. During warming from $10{ }^{\circ} \mathrm{C}$ to $28{ }^{\circ} \mathrm{C}$ no significant 

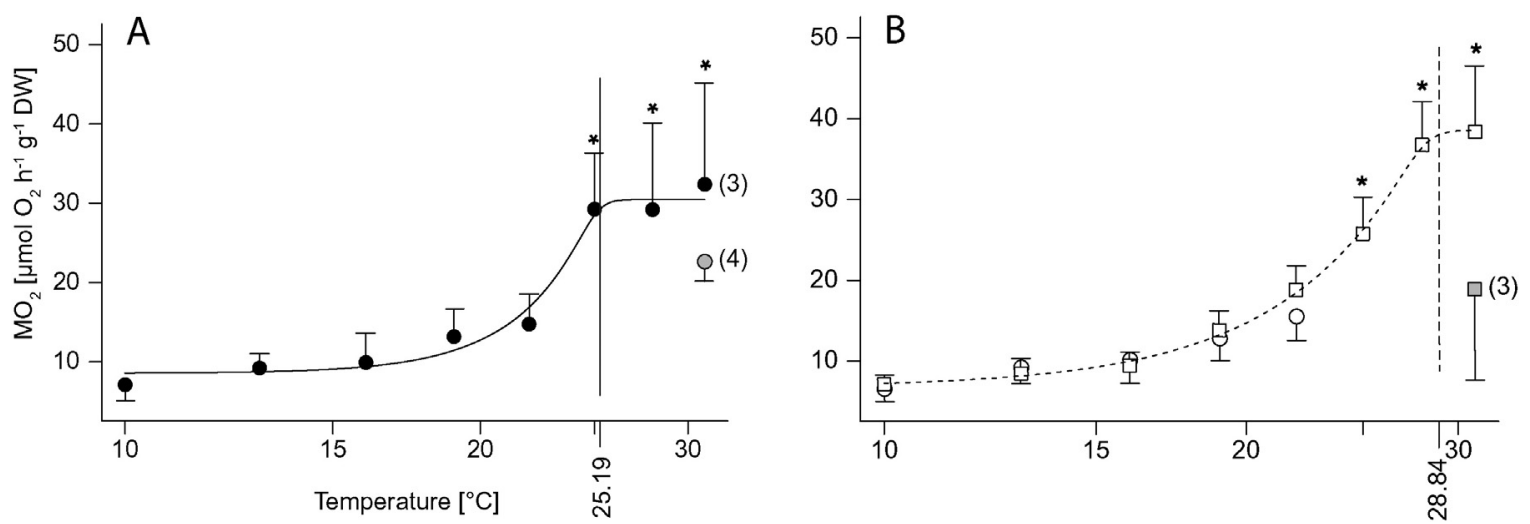

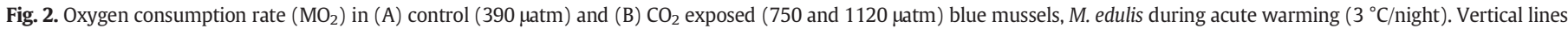

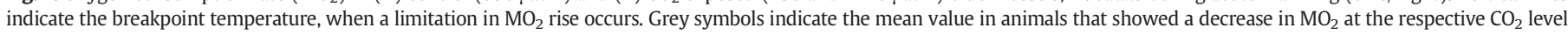
(for details see text). The number of animals is given in parentheses if below $5 .{ }^{*}=$ significantly different from the respective data at $10{ }^{\circ} \mathrm{C}$.

changes occurred (Fig. 3), however, the additional increase to $31{ }^{\circ} \mathrm{C}$ resulted in a significant accumulation of succinate under both normocapnia and hypercapnia (390 $\mu$ atm: $0.12 \pm 0.03$ a.u. at $10^{\circ}$ vs. $0.61 \pm 0.33$ at $31^{\circ} \mathrm{C}, \mathrm{P}<0.001 ; 1120 \mu$ atm: $0.08 \pm 0.03$ a.u. at $10{ }^{\circ} \mathrm{C}$ vs. $0.61 \pm 0.16$ at $\left.31^{\circ} \mathrm{C}, \mathrm{P}<0.001\right)$. Accordingly, two-way ANOVA identified a main effect only for temperature $(\mathrm{P}<0.001)$.

Oxygenation and acid-base status determined in extrapallial fluids were similar to the ones in haemolymph (Table 4), therefore only haemolymph data are described here. Haemolymph $\mathrm{PO}_{2}$ showed high inter-individual variability. Two-way ANOVA suggested a significant effect of temperature and of the interaction between temperature and $\mathrm{CO}_{2}$ on haemolymph $\mathrm{PO}_{2}(\mathrm{P}<0.001$ and $\mathrm{P}=0.044$, respectively $)$. However, post hoc analyses did not reveal significant differences during warming when compared to acclimation temperature $\left(10^{\circ} \mathrm{C}\right)$ or between the $\mathrm{CO}_{2}$ treatments at a specific temperature likely due to high inter-individual variability (Fig. 4A). In normocapnic mussels haemolymph $\mathrm{PO}_{2}$ shows a trend to decrease during warming from $116.4 \pm 5.2$ Torr at $10{ }^{\circ} \mathrm{C}$ to $85.0 \pm 29.2$ Torr at $31^{\circ} \mathrm{C}$, which resembles the decline under hypercapnia when initial $\mathrm{PO}_{2}$ values at $10{ }^{\circ} \mathrm{C}$ were somewhat lower than in control $\mathrm{PCO}_{2}$ incubations (750 $\mu \mathrm{atm}$ : from $102.6 \pm 12.2$ Torr at $10{ }^{\circ} \mathrm{C}$ to $80.2 \pm 10.5$ at $22{ }^{\circ} \mathrm{C} ; 1120 \mu$ atm: from $100.1 \pm 13.1$ Torr at $10{ }^{\circ} \mathrm{C}$ to $87.2 \pm 22.8$ at $31{ }^{\circ} \mathrm{C}$ ). Post hoc tests confirmed a significant decrease only between $13^{\circ}$ and $31{ }^{\circ} \mathrm{C}$ under normocapnia, again due to the high variability of data.

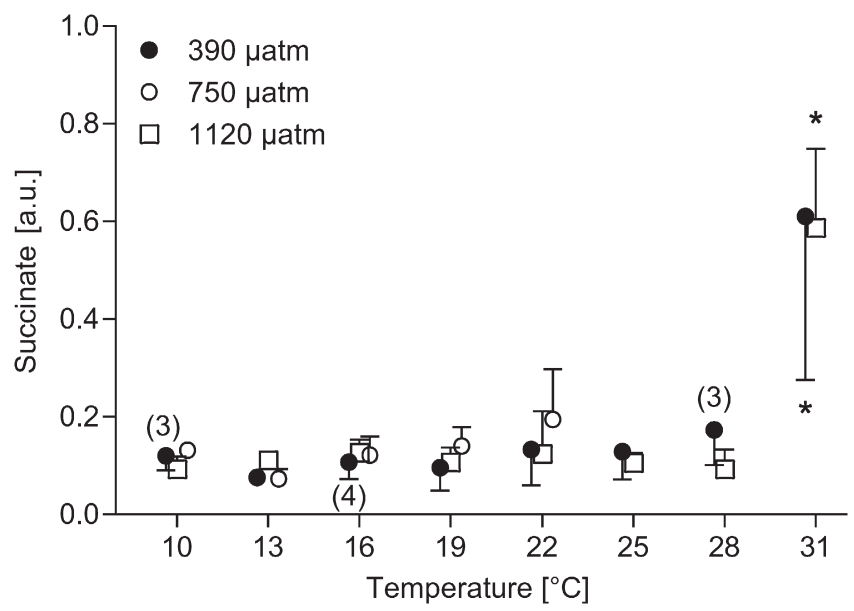

Fig. 3. Succinate content in mantle tissue of control ( $390 \mu \mathrm{utm}$ ) and $\mathrm{CO}_{2}$ exposed ( 750 and $1120 \mu \mathrm{atm}$ ) blue mussels, $M$. edulis during acute warming ( $3^{\circ} \mathrm{C} /$ night). The number of animals is given in parentheses if below $5 .{ }^{*}=$ significantly different from the respective data at $10{ }^{\circ} \mathrm{C}$.
Haemolymph $\mathrm{PCO}_{2}$ did not show significant differences between $\mathrm{CO}_{2}$ treatments throughout the experimental period (Fig. 4B). While no changes occurred during warming from 10 to $28^{\circ} \mathrm{C}$, further warming to $31{ }^{\circ} \mathrm{C}$ resulted in a significant increase of haemolymph $\mathrm{PCO}_{2}$ in both normocapnic and hypercapnic animals, with a somewhat stronger increase in the former ones ( $390 \mu$ atm: $0.93 \pm 0.23$ at $10{ }^{\circ} \mathrm{C}$ vs. $10.83 \pm$ 4.57 Torr at $31{ }^{\circ} \mathrm{C}, \mathrm{P}<0.001 ; 1120 \mu$ atm: $1.77 \pm 0.52$ at $10{ }^{\circ} \mathrm{C}$ vs. $7.79 \pm 3.01$ Torr at $\left.31{ }^{\circ} \mathrm{C}, \mathrm{P}<0.001\right)$.

Haemolymph $\mathrm{pH}$ of $M$. edulis displayed different patterns depending on $\mathrm{CO}_{2}$ treatment during acute warming between $10{ }^{\circ} \mathrm{C}$ and $31{ }^{\circ} \mathrm{C}$ (Fig. $4 \mathrm{C}$ ). pH was significantly affected by temperature, $\mathrm{CO}_{2}$ treatment and their interaction $(\mathrm{P}<0.001, \mathrm{P}=0.003, \mathrm{P}=0.016$, respectively). $\mathrm{pH}$ values remained highest under normocapnia. They fell significantly during the first temperature rise from $7.65 \pm 0.06$ at $10{ }^{\circ} \mathrm{C}$ to $7.39 \pm$ 0.05 at $13{ }^{\circ} \mathrm{C}(\mathrm{P}=0.005)$, and remained relatively stable thereafter until they dropped significantly from $7.38 \pm 0.08$ at $22{ }^{\circ} \mathrm{C}$ to $7.01 \pm$ 0.25 at $25{ }^{\circ} \mathrm{C}(\mathrm{P}<0.001)$, with no further change until $31{ }^{\circ} \mathrm{C}(7.02 \pm$ 0.05). In contrast, haemolymph pH under $750 \mu$ atm of hypercapnia started with a value of $7.41 \pm 0.12$ at $10{ }^{\circ} \mathrm{C}(\mathrm{P}=0.028)$, significantly lower than under normocapnia, but reached $7.34 \pm 0.11$ at $22^{\circ} \mathrm{C}$, similar to the value seen under normocapnia. Mussels under hypercapnic conditions of $1120 \mu \mathrm{atm}$ displayed a slight decrease from $7.48 \pm$ 0.15 at $10{ }^{\circ} \mathrm{C}$ to $7.29 \pm 0.06$ at $22{ }^{\circ} \mathrm{C}$ followed by a drop to $7.10 \pm$ 0.11 at $25^{\circ} \mathrm{C}$, significantly lower than at acclimation temperature $(\mathrm{P}<$ 0.001 ), with no further changes thereafter. A sudden drop in haemolymph pH between $22{ }^{\circ} \mathrm{C}$ and $25^{\circ} \mathrm{C}$ thus occurred independent of $\mathrm{CO}_{2}$ treatment. As data between $10{ }^{\circ} \mathrm{C}$ and $22{ }^{\circ} \mathrm{C}$ are the results from the 1st run and the ones between $25{ }^{\circ} \mathrm{C}$ and $31{ }^{\circ} \mathrm{C}$ from the 2nd run (see experimental protocol in Section 2.3 ) it seemed conceivable that the observed drop resulted from combining the two data sets. However, occasional measurements performed below $25{ }^{\circ} \mathrm{C}$ in the 2 nd

\section{Table 4}

Haemolymph (HL) vs. extrapallial fluid (EPF) acid-base status in control (390 $\mu$ atm) and $\mathrm{CO}_{2}$ exposed (750 and $1120 \mu \mathrm{atm}$ ) blue mussels, $M$. edulis at control temperature (10 ${ }^{\circ} \mathrm{C}$ ) and at the end of the warming protocol $\left(31^{\circ} \mathrm{C}\right) . \mathrm{N}=3-7$.

\begin{tabular}{lllrrll}
\hline $\mathrm{CO}_{2}$ exposure & $\mathrm{T}{ }^{\circ} \mathrm{C}$ & Fluid & $\mathrm{PO}_{2}$ Torr & \multicolumn{1}{l}{$\mathrm{PCO}_{2}$ Torr } & \multicolumn{1}{l}{$\mathrm{pH}_{\mathrm{NBS}}$} & $\mathrm{CCO}_{2}[\mathrm{mM}]$ \\
\hline $390 \mu \mathrm{atm}$ & \multirow{2}{*}{10} & $\mathrm{HL}$ & \multicolumn{1}{c}{$116 \pm 5$} & $0.93 \pm 0.23$ & $7.65 \pm 0.06$ & $1.53 \pm 0.19$ \\
& & $\mathrm{EPF}$ & $128 \pm 23$ & $0.89 \pm 0.18$ & $7.55 \pm 0.10$ & $1.34 \pm 0.07$ \\
$750 \mu \mathrm{atm}$ & 10 & $\mathrm{HL}$ & $103 \pm 12$ & $1.80 \pm 0.20$ & $7.41 \pm 0.12$ & $1.83 \pm 0.23$ \\
& & $\mathrm{EPF}$ & $113 \pm 26$ & $2.06 \pm 0.57$ & $7.35 \pm 0.10$ & $2.31 \pm 0.25$ \\
$1120 \mu \mathrm{atm}$ & \multirow{2}{*}{10} & $\mathrm{HL}$ & $100 \pm 13$ & $1.77 \pm 0.52$ & $7.48 \pm 0.15$ & $2.36 \pm 0.06$ \\
& & $\mathrm{EPF}$ & $115 \pm 17$ & $1.35 \pm 0.68$ & $7.51 \pm 0.07$ & $2.37 \pm 0.25$ \\
$390 \mu \mathrm{atm}$ & \multirow{2}{*}{31} & $\mathrm{HL}$ & $85 \pm 29$ & $10.83 \pm 4.57$ & $7.02 \pm 0.05$ & $4.05 \pm 1.20$ \\
& & $\mathrm{EPF}$ & $110 \pm 14$ & $8.88 \pm 3.19$ & $6.93 \pm 0.13$ & $3.75 \pm 1.11$ \\
$1120 \mu \mathrm{atm}$ & \multirow{2}{*}{31} & $\mathrm{HL}$ & $87 \pm 23$ & $7.79 \pm 3.01$ & $7.12 \pm 0.11$ & $2.51 \pm 0.47$ \\
& & $\mathrm{EPF}$ & $103 \pm 20$ & $9.29 \pm 3.08$ & $7.02 \pm 0.04$ & $2.88 \pm 0.47$
\end{tabular}



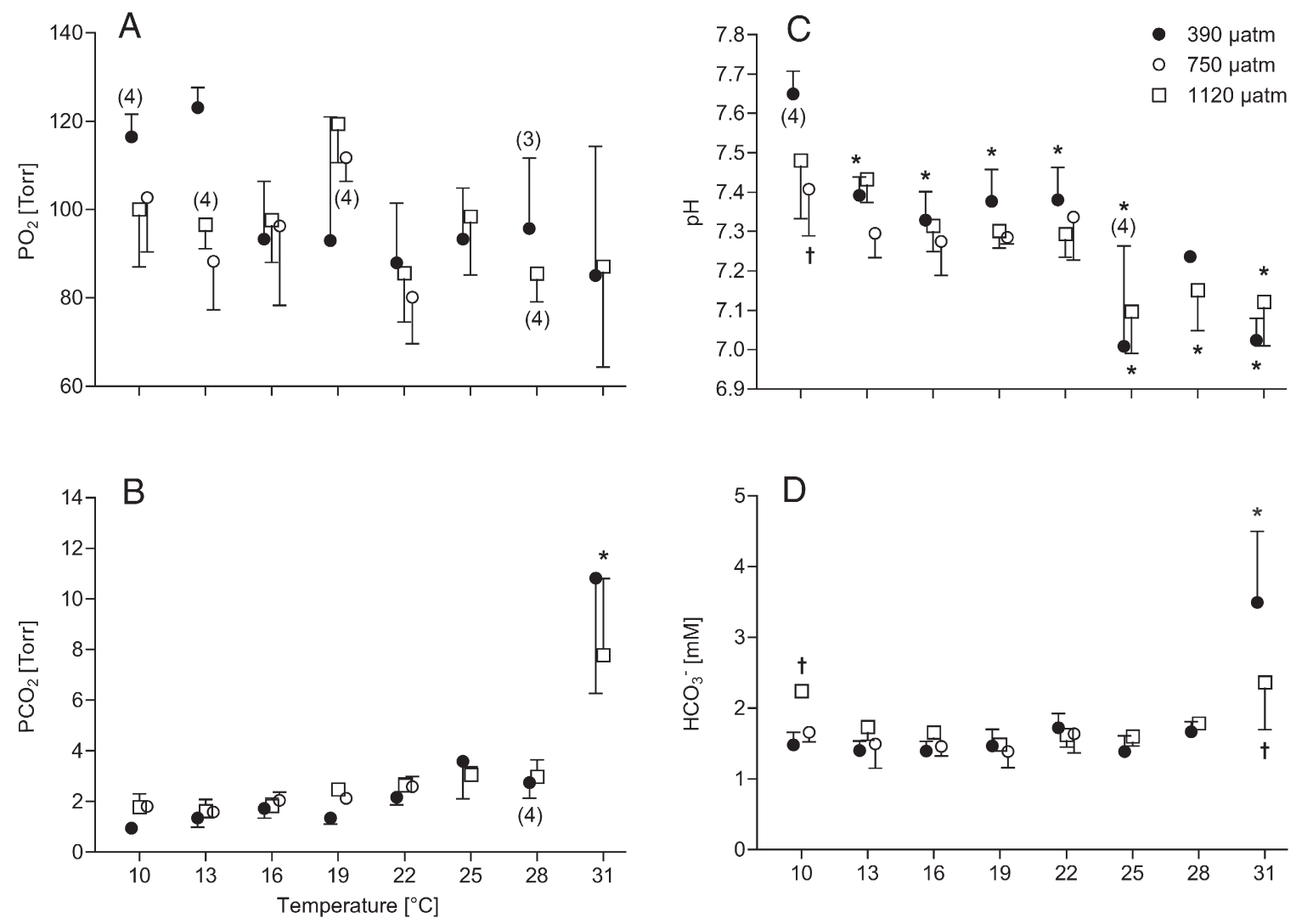

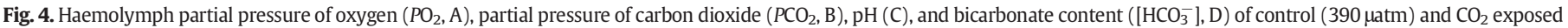

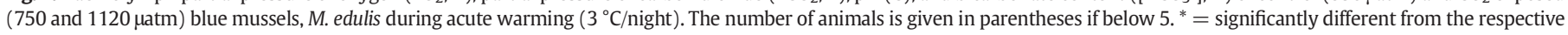
data at $10{ }^{\circ} \mathrm{C}, \dagger=$ significantly different between control and $\mathrm{CO}_{2}$ exposed mussels at the respective temperature.

run checked for the comparability of the data sets and these values confirmed the existence of the overproportional drop (data not shown).

At $10{ }^{\circ} \mathrm{C}$ haemolymph bicarbonate concentration $\left(\left[\mathrm{HCO}_{3}^{-}\right]\right)$increased significantly from $1.48 \pm 0.18$ under normocapnia to $2.24 \pm$ $0.07 \mathrm{mM}$ at $1120 \mu \mathrm{atm}(\mathrm{P}=0.047$ ) (Fig. 4D). During acute warming from $10{ }^{\circ} \mathrm{C}$ to $31{ }^{\circ} \mathrm{C}$ further changes in haemolymph $\left[\mathrm{HCO}_{3}^{-}\right]$depended on the $\mathrm{CO}_{2}$ treatment. In normocapnic mussels between $10^{\circ} \mathrm{C}$ and $28^{\circ} \mathrm{C}$, haemolymph $\left[\mathrm{HCO}_{3}^{-}\right]$remained relatively constant around $1.48 \pm$ $0.18 \mathrm{mM}$ and increased significantly to a maximum of $3.50 \pm$ $1.00 \mathrm{mM}$ at $31{ }^{\circ} \mathrm{C}(\mathrm{P}<0.001)$. In contrast, haemolymph $\left[\mathrm{HCO}_{3}^{-}\right]$concentrations under $750 \mu$ atm varied slightly from $1.66 \pm 0.14$ at $10{ }^{\circ} \mathrm{C}$ to $1.39 \pm 0.23 \mathrm{mM}$ at $19{ }^{\circ} \mathrm{C}$ and $1.64 \pm 0.27 \mathrm{mM}$ at $22^{\circ} \mathrm{C}$. Haemolymph $\left[\mathrm{HCO}_{3}^{-}\right]$at $1120 \mu$ atm decreased progressively from $2.24 \pm 0.07$ at $10{ }^{\circ} \mathrm{C}$ to a minimum of $1.49 \pm 0.07 \mathrm{mM}$ at $19{ }^{\circ} \mathrm{C}$ and started to increase thereafter to $2.37 \pm 0.67 \mathrm{mM}$ at $31^{\circ} \mathrm{C}$, significantly higher than found at $19^{\circ} \mathrm{C}, 22{ }^{\circ} \mathrm{C}$ and $25^{\circ} \mathrm{C}(\mathrm{P}=0.007, \mathrm{P}=0.037, \mathrm{P}=0.026$, respectively $)$. Two-way ANOVA identified a significant interaction between temperature and $\mathrm{CO}_{2}$ treatment $(\mathrm{P}<0.001)$ and a main effect of temperature $(\mathrm{P}<0.001)$.

At control temperature, haemolymph $\left[\mathrm{HCO}_{3}^{-}\right]$concentration was significantly higher under hypercapnia $(1120 \mu \mathrm{atm}, \mathrm{P}=0.047)$ than normocapnia, despite the lower $\mathrm{pH}$ value under hypercapnia. The difference was eliminated during acute warming until temperature rose from $28{ }^{\circ} \mathrm{C}$ to $31^{\circ} \mathrm{C}$, which resulted in a significantly higher $\left[\mathrm{HCO}_{3}^{-}\right]$ level in normocapnic mussels than in hypercapnic ones $(\mathrm{P}<0.001)$.

Fig. 5 (normocapnia, $390 \mu \mathrm{atm}$ ) and Fig. 6 (hypercapnia, $1120 \mu \mathrm{atm}$ ) depict the comparison between haemolymph $\mathrm{pH}$ on the one hand and heart rate (A) or oxygen consumption (B), on the other hand. It should be noted that heart rates above $22{ }^{\circ} \mathrm{C}$ were only available from $\mathrm{N}=1-2$ animals per treatment (see figures and Section 2.4), such that statistical analysis was only possible for data from $10{ }^{\circ} \mathrm{C}$ to $22^{\circ} \mathrm{C}$. Hypercapnia at 750 (not shown) and $1120 \mu$ atm had no significant effect on heart rate of M. edulis between $10{ }^{\circ} \mathrm{C}$ and $22^{\circ} \mathrm{C}$, when compared to normocapnia. Regardless of $\mathrm{CO}_{2}$ treatment, acute warming between $10{ }^{\circ} \mathrm{C}$ and $22{ }^{\circ} \mathrm{C}$ caused heart rates to rise progressively to significantly higher values at $19{ }^{\circ} \mathrm{C}$ than at acclimation temperature $(\mathrm{P}=0.001$ at $390, \mathrm{P}=$ 0.011 at $750, \mathrm{P}<0.001$ at $1120 \mu \mathrm{atm})$. Two-way ANOVA suggested a significant effect of temperature $(\mathrm{P}<0.001)$ and $\mathrm{CO}_{2}(\mathrm{P}<0.001)$ but the post hoc test did not confirm any differences between the three $\mathrm{CO}_{2}$ treatments. During further warming, the increase in heart rate became limited above or at $25{ }^{\circ} \mathrm{C}$ under both normocapnia and hypercapnia $(1120 \mu \mathrm{atm})$. While heart rate under hypercapnia levelled off above $25^{\circ} \mathrm{C}$, rates under normocapnia levelled off and started to decrease at $31^{\circ} \mathrm{C}$. The limitation to a further increase in heart rate occurred when haemolymph pH had suddenly dropped below 7.3 regardless of $\mathrm{CO}_{2}$ treatment (Figs. 5A and 6A). In normocapnic mussels the same pattern was found for oxygen consumption: when haemolymph $\mathrm{pH}$ had dropped the limitation to a further rise in $\mathrm{MO}_{2}$ became effective (Fig. 5B). In contrast, hypercapnic mussels showed a further exponential increase in $\mathrm{MO}_{2}$ until $28{ }^{\circ} \mathrm{C}$ regardless of acidosis (Fig. 6B).

\section{Discussion}

The aim of this study was to investigate the interacting effects of temperature and $\mathrm{CO}_{2}$ levels according to near future ocean acidification scenarios, and to interpret the data by use of the OCLTT concept.

\subsection{Thermal limits under normocapnia}

Oxygen consumption rate $\left(\mathrm{MO}_{2}\right)$ of $M$. edulis at acclimation temperature $\left(10^{\circ} \mathrm{C}\right)$ ranged between 4.4 and $9.8 \mu \mathrm{mol} \mathrm{O}_{2} \mathrm{~h}^{-1} \mathrm{~g} \mathrm{DW}^{-1}$ under normocapnia ( $390 \mu \mathrm{atm})$. Rates were found well in the range of previously published data for M. edulis (Okumus and Stirling, 1994; Schlüter and Johansen, 1994; Sukhotin and Pörtner, 2001). Acute 


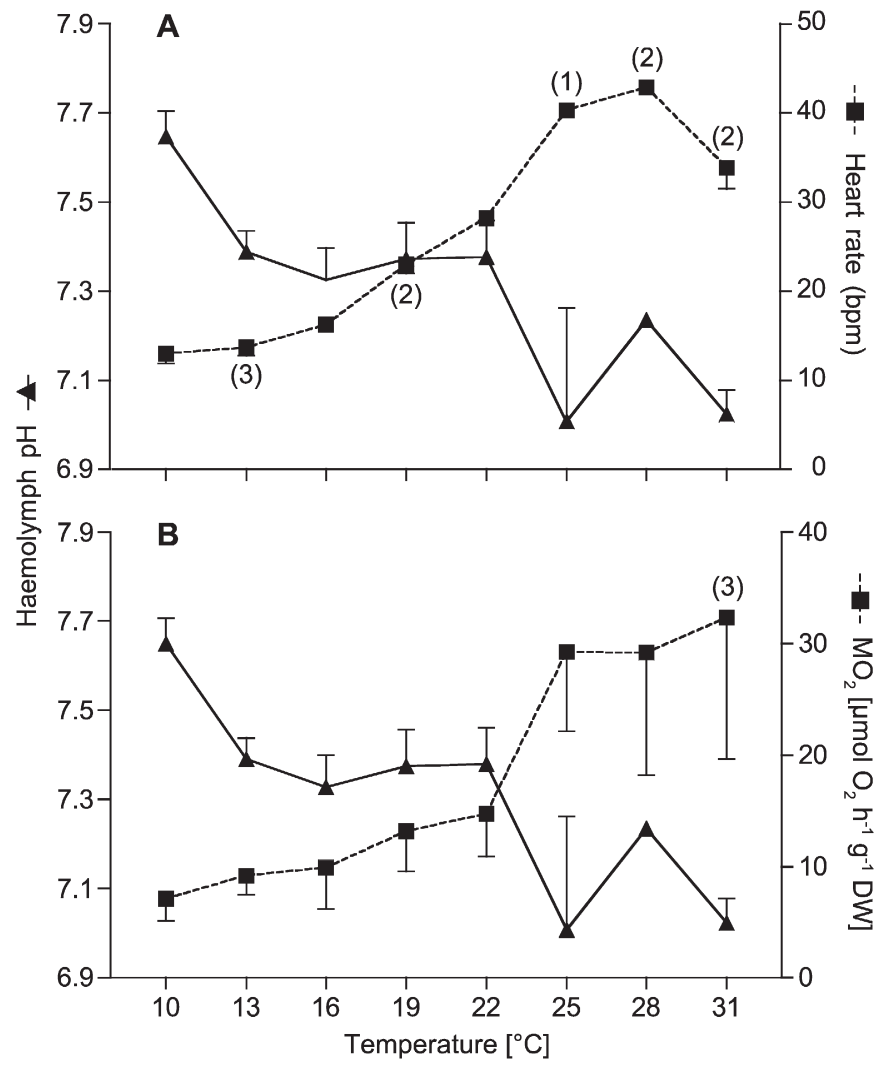

Fig. 5. Combined depiction of haemolymph pH and (A) heart rate or (B) $\mathrm{MO}_{2}$ of Mytilus edulis during acute warming $\left(3^{\circ} \mathrm{C} /\right.$ night $)$ under normocapnia $(390 \mu \mathrm{atm})$. The number of animals is given in parentheses if below 4 .

warming from $10{ }^{\circ} \mathrm{C}$ to $31{ }^{\circ} \mathrm{C}$ resulted in a progressive rise in $\mathrm{MO}_{2}$ following a $\mathrm{Q}_{10}$-value $\left(10-28{ }^{\circ} \mathrm{C}\right)$ of 2.19 . During the last temperature rise from $28{ }^{\circ} \mathrm{C}$ to $31^{\circ} \mathrm{C}, 43 \%$ ( 3 of 7 ) of the animals were able to further increase their $\mathrm{MO}_{2}$ while the others showed a decrease. This suggests that about half of the animals had exceeded their critical temperature limit, likely due to lower individual performance capacity. These findings of anaerobic metabolite accumulation and haemolymph $\mathrm{PCO}_{2}$ confirmed that the critical temperature $\left(\mathrm{T}_{\mathrm{C}}\right)$ was reached above $28{ }^{\circ} \mathrm{C}$ (discussed below).

Interestingly, a phase change in the $\mathrm{MO}_{2}$ rise during acute warming was found at a calculated breakpoint temperature of $25.2{ }^{\circ} \mathrm{C}$ (Fig. $2 \mathrm{~A}$, vertical line). This breakpoint indicates the onset of a limitation in oxygen supply, and might involve metabolic depression. According to the OCLTT concept the progressive reduction in the scope for oxygen supply may be caused by a rise in baseline energy demand, paralleled by a capacity limit of cardiac performance reached at the pejus temperature $\left(T_{P}\right)$ (Pörtner, 2001). In accordance, a limitation in heart rate was also observed above $25{ }^{\circ} \mathrm{C}$ (see below). The present findings allow to put changes in extracellular $\mathrm{pH}$ into this context. The correlation between haemolymph $\mathrm{pH}$ on the one hand and oxygen consumption or heart rate, on the other hand (see Fig. 5) indicates that a sudden drop in haemolymph pH between $22{ }^{\circ} \mathrm{C}$ and $25{ }^{\circ} \mathrm{C}$ might have influenced the subsequent course of the other parameters. Beyond $25^{\circ} \mathrm{C}$ the $\mathrm{Q}_{10}$ of $\mathrm{MO}_{2}$ fell close to 1 possibly due to metabolic depression induced by falling extracellular pH as reported by Reipschläger and Pörtner (1996) and Michaelidis et al. (2005). Mytilus, as an inhabitant of sub- and intertidal zones, is adapted to daily temperature fluctuations. Consequently, it is most likely that M. edulis in the North Sea is exploiting mechanisms such as metabolic depression to passively withstand short-term acute temperature extremes (e.g. Connor and Gracey, 2012). A putative $T_{P}$ of around $25{ }^{\circ} \mathrm{C}$ is also supported by earlier studies on $M$. edulis from the North Sea, where several physiological parameters such as ventilation

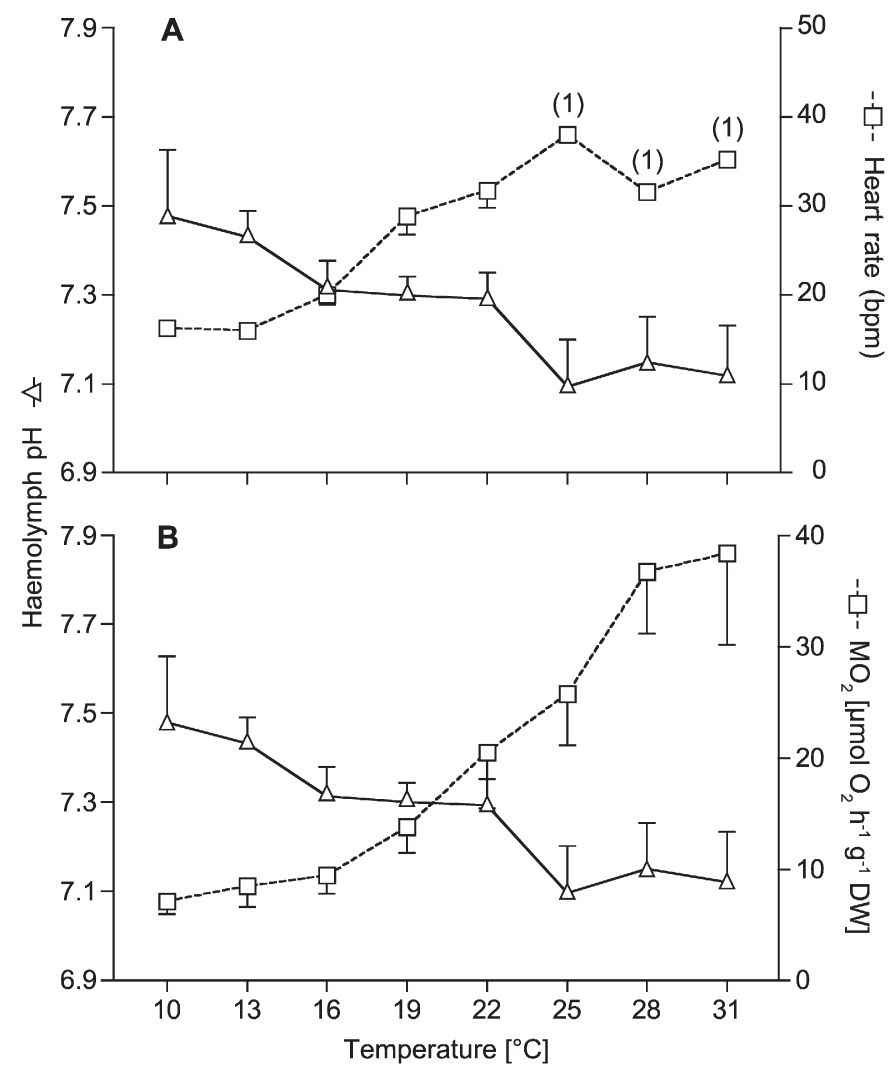

Fig. 6. Combined depiction of haemolymph pH and (A) heart rate or (B) $\mathrm{MO}_{2}$ of Mytilus edulis during acute warming $\left(3{ }^{\circ} \mathrm{C} /\right.$ night $)$ under hypercapnia $(1120 \mu \mathrm{atm})$. The number of animals is given in parentheses if below 4 .

rate, filtration rate and the scope for growth and activity were reduced at around this temperature (Bayne et al., 1973; Widdows, 1973a, 1973b, 1976).

These findings indicate a relationship between metabolic rate transitions at thermal limits and underlying modes of metabolism quite different from those observed in a cephalopod mollusc and in fishes (Mark, 2001; Melzner, 2005; Melzner et al., 2006). In those groups the phase change in $\mathrm{MO}_{2}$ was suggested to be an indicator of $\mathrm{T}_{\mathrm{C}}$, whereas mussels may respond by metabolic depression already at $\mathrm{T}_{\mathrm{p}}$. Fish and cephalopods possess a closed circulatory system and strong ion regulation capacity. These characters may delay the onset of metabolic depression during environmental challenges. Also, they may not exploit or express any capacity to depress energy demand due to their permanently submerged mode of life.

A heart rate of $13 \pm 2 \mathrm{bpm}$ at acclimation temperature $\left(10^{\circ} \mathrm{C}\right)$ is in good agreement with data published previously for $M$. edulis at similar salinities and temperatures (Braby and Somero, 2006; Widdows, 1973b). Upon acute warming, heart rate increased progressively up to $25^{\circ} \mathrm{C}$ and levelled off thereafter (indicating $\mathrm{T}_{\mathrm{p}}$, see discussion above) before a decrease was found at $31^{\circ} \mathrm{C}$. The onset of a drop in heart rate indicates the progressive break down of the circulatory system and thus $\mathrm{T}_{\mathrm{C}}\left(>28^{\circ} \mathrm{C}\right)$ (Frederich and Pörtner, 2000) supporting the conclusions from the $\mathrm{MO}_{2}$ data. The temperature-dependent heart rates of the present study are in line with findings by Widdows (1973b) in M. edulis acclimated at $15{ }^{\circ} \mathrm{C}$. These animals displayed a progressive increase in heart rate up to $25^{\circ} \mathrm{C}$ followed by a drastic drop at $30^{\circ} \mathrm{C}$.

The critical temperature is the physiological limit where oxygen supply becomes insufficient resulting in a transition to anaerobic metabolism (for review, see Pörtner, 2010). The onset of anaerobic metabolism is indicated by the accumulation of succinate, a key anaerobic metabolite of bivalve mitochondria (Zurburg and Kluytmans, 1980; Sukhotin and Pörtner, 1999; Hines et al., 2007). In fact, a sharp 
increase in succinate concentration occurred in mantle tissue above $28{ }^{\circ} \mathrm{C}$ (Fig. 3A). The involvement of anaerobic metabolism can be explained by a fall in blood $\mathrm{PO}_{2}$ to levels too low for sustained oxygen diffusion to all mitochondria, as demonstrated for several marine taxa (Frederich and Pörtner, 2000; Lannig et al., 2004). Peck et al. (2002) showed that warming in the Antarctic bivalve Laternula elliptica first leads to a slight decrease in haemolymph $\mathrm{PO}_{2}$ until the critical temperature was reached due to a subsequent drop by $>70 \%$ to a level of 20.3 Torr. Haemolymph $\mathrm{PO}_{2}$ of mussels in the present study indicated a decreasing trend with warming but values remained quite high even above $28^{\circ} \mathrm{C}$ ( $\sim 85$ Torr) when succinate increased and $\mathrm{T}_{\mathrm{C}}$ was reached. The same pattern was found in a comparative study on $M$. edulis from the White Sea (Zittier et al., in prep.). In the present study, haemolymph samples were collected from the posterior adductor muscle, whereas Peck et al. (2002) took samples directly from the pericardium. Mussels have an open circulatory system where blood is pumped into a number of open sinuses within tissue and organs, which are supposed to contain a mixture of pre- and postbranchial haemolymph (Booth et al., 1984; Walsh et al., 1984), before it is returned via main vessels into the heart. Therefore, haemolymph sampled directly from the pericardium might be a more suitable indicator of thermal limitation in oxygen supply. However, a drastic increase in haemolymph $\mathrm{PCO}_{2}$ at critical temperatures was found, potentially emphasized by the acidification and uncompensated by gas exchange above $28{ }^{\circ} \mathrm{C}$, which is in line with the beginning limitation of respiratory and cardiovascular capacity (see above). Therefore, in this study the $\mathrm{PCO}_{2}$ more than $\mathrm{PO}_{2}$ of haemolymph may be a suitable indicator for characterizing critical limits.

Extrapallial fluid and haemolymph yielded similar oxygenation and acid-base variables in all experimental groups. This supports the observations by Thomsen et al. (2010) that both fluids are characterized by a similar carbonate system, also recently described in M. galloprovincialis (Gazeau et al., 2014). Therefore, only haemolymph data are discussed here. All haemolymph parameters determined in this study under control conditions (normocapnia, $10^{\circ} \mathrm{C}$ ) are in good agreement with values previously reported for $M$. edulis (e.g. Booth et al., 1984). During the first temperature rise from $10{ }^{\circ} \mathrm{C}$ to $13^{\circ} \mathrm{C}$ haemolymph pH dropped significantly and remained relatively stable thereafter until a second significant drop from $7.38 \pm 0.08$ to $7.01 \pm 0.25$ occurred between $22{ }^{\circ} \mathrm{C}$ and $25^{\circ} \mathrm{C}$. A reduced extracellular $\mathrm{pH}$ can induce metabolic depression in marine invertebrates (e.g. Reipschläger and Pörtner, 1996). Accordingly, the second drop in $\mathrm{pH}$ was accompanied by stagnating $\mathrm{MO}_{2}$ rates, which might reflect the above mentioned metabolic depression at or above $25^{\circ} \mathrm{C}$. These findings might suggest that an extracellular $\mathrm{pH}$ lower than 7.3 induces metabolic depression in M. edulis from the North Sea. In M. edulis from the Baltic Sea $\mathrm{CO}_{2}$ exposure to $4000 \mu \mathrm{tm}$ at constant temperatures led to haemolymph pH of 7.1 (Thomsen et al., 2010), which had no impact on the metabolic rate determined in a parallel study under the same conditions (Thomsen and Melzner, 2010). In contrast, in M. galloprovincialis from the Mediterranean Sea exposed to $\sim 5000 \mu$ atm aerobic metabolism was already depressed at a haemolymph pH of 7.4 (Michaelidis et al., 2005). These findings suggest that the $\mathrm{pH}$ threshold inducing metabolic depression is species and possibly population specific, and may as well be influenced by temperature and subject to adaptation to high $\mathrm{CO}_{2}$ environments. Sensitivity to hypercapnia induced extracellular acidosis may correlate with the $\mathrm{PCO}_{2}$ fluctuations a species encounters in its natural environment. In contrast to relative stable $\mathrm{CO}_{2}$ levels in the northern North Sea (see Section 2.1) seawater $\mathrm{PCO}_{2}$ in the Western Baltic Sea is elevated for most of the year (average $~ 700 \mu \mathrm{atm}$ ) reaching peak values of $>2300 \mu \mathrm{atm}$ during summer and autumn (Thomsen et al., 2010).

Lower invertebrates like bivalves and echinoderms are considered weak acid-base regulators that can tolerate an extracellular acidosis up to a certain point. Interestingly, mussels allowed extracellular $\mathrm{pH}$ to fluctuate passively during short-term warming on timescales longer than occurring in the intertidal. Only when a strong and sudden increase in haemolymph $\mathrm{PCO}_{2}$ occurred at the critical temperature $M$. edulis started to defend its internal milieu against further acidification by $\left[\mathrm{HCO}_{3}^{-}\right]$accumulation. In mussels, $\left[\mathrm{HCO}_{3}^{-}\right]$can partially derive from dissolution of the $\mathrm{CaCO}_{3}$ shell (Lindinger et al., 1984, > 34,200 $\mu \mathrm{atm}$; Michaelidis et al., 2005, $5000 \mu \mathrm{atm})$. As this process occurs in longer term under moderate hypercapnia (Michaelidis et al., 2005; Melzner et al., 2011, $4000 \mu \mathrm{atm}$ ), the sudden increase in $\left[\mathrm{HCO}_{3}^{-}\right]$observed in the present study likely results from active $\mathrm{pH}$ regulation through proton equivalent ion exchange potentially stimulated by reaching the upper thermal limit provoking a last effort on defence.

\section{2. $\mathrm{CO}_{2}$ effects on thermal limits}

Hypercapnia (750 and $1120 \mu \mathrm{atm}$ ) had no effect on oxygen consumption $\left(\mathrm{MO}_{2}\right)$ of $\mathrm{M}$. edulis at acclimation temperature $\left(10^{\circ} \mathrm{C}\right)$ when compared to normocapnia ( $390 \mu \mathrm{atm})$ indicating neither elevated energy demand nor metabolic depression in mildly hypercapnic animals. Consistent with these results, recent studies imply that short- and long-term moderate hypercapnia exposures ( $\leq 2000 \mu \mathrm{atm}$ ) have almost no significant impact on aerobic metabolic rates of bivalves (Lannig et al., 2010; Thomsen and Melzner, 2010; Schalkhausser et al., 2012). However, findings by Michaelidis et al. (2005) and Thomsen and Melzner (2010) indicate that more extreme $\mathrm{PCO}_{2}$ levels (>4000 $\mu \mathrm{atm}$ ) will likely cause a downregulation of energy demand and metabolic rates in Mytilus species.

Acute warming (750 $\mu \mathrm{atm}: 10-22{ }^{\circ} \mathrm{C}, 1120 \mu \mathrm{atm}: 10-31{ }^{\circ} \mathrm{C}$; $3{ }^{\circ} \mathrm{C}$ /night) caused a progressive rise in $\mathrm{MO}_{2}$, which became significantly elevated above $22{ }^{\circ} \mathrm{C}$. Metabolic stimulation was somewhat stronger under hypercapnia ( $1120 \mu \mathrm{atm})$ leading to a slightly but not significantly higher $\mathrm{Q}_{10^{-}}$-value $\left(10-28^{\circ} \mathrm{C}\right)$ than in control animals ( $2.49 \mathrm{vs.} 2.19$, respectively). For comparison, oysters (Crassostrea gigas) showed (significantly) higher $\mathrm{Q}_{10}$-values after acute warming $\left(5-25{ }^{\circ} \mathrm{C}\right.$, $\left.5{ }^{\circ} \mathrm{C} / 48 \mathrm{~h}\right)$ under hypercapnia $\left(\mathrm{PCO}_{2}=1500 \mu \mathrm{atm}\right)$ compared to normocapnia (Lannig et al., 2010). In their study animals were exposed to long-term hypercapnia (26-55 days vs. 14 days in the present study) before experimentation, which had no impact on oyster metabolic rates but resulted in a decreased body condition index. This suggests reduced growth efficiency and, hence, indicating shifts in energy allocation, possibly exacerbated by starvation. Similarly, long-term moderate hypercapnia at constant temperatures had no impact on metabolic rates in blue mussels but reduced shell growth rates (M. edulis: Berge et al.,

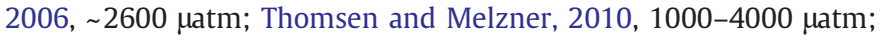
M. galloprovincialis: Michaelidis et al., 2005, $5000 \mu \mathrm{atm})$. Hence, longer exposure times to hypercapnia would likely exacerbate the effect of warming on energy demand resulting in a significantly increased $Q_{10}$ than under normocapnia as seen in oysters.

During the last temperature step from $28^{\circ} \mathrm{C}$ to $31^{\circ} \mathrm{C}$, only $63 \%$ (5 out of $8 ; 1120 \mu \mathrm{atm}$ ) of the mussels were able to increase their $\mathrm{MO}_{2}$ further, while others showed a decrease as seen under normocapnia. These findings suggest that the hypercapnic $\mathrm{T}_{\mathrm{C}}$ was reached at the same temperature as under normocapnia, confirmed by anaerobic metabolite and haemolymph $\mathrm{PCO}_{2}$ data (see below). However, the $\mathrm{MO}_{2}$ course under hypercapnia showed a somewhat higher mean slope and consequently does not reflect metabolic depression in all animals, at least up to $28^{\circ} \mathrm{C}$. The data indicate an increase in variability in the response. The discontinuity in $\mathrm{MO}_{2}$ under hypercapnia occurred at a calculated breakpoint temperature of $28.84^{\circ} \mathrm{C}$ and thus, close to the $\mathrm{T}_{\mathrm{C}}$. In contrast, the discontinuity in normocapnic animals occurred at lower temperature $\left(25.19^{\circ} \mathrm{C}\right)$, was attributed to metabolic depression and interpreted to mark onset of the pejus range. The $T_{P}$ of hypercapnic mussels seems to be similar as haemolymph pH dropped during the temperature rise from $22^{\circ} \mathrm{C}$ to $25^{\circ} \mathrm{C}$ followed by a restriction of cardiac performance beyond $25^{\circ} \mathrm{C}$ (see Fig. 6 ) as seen in normocapnic mussels. Overall, the data indicate that during warming, $\mathrm{CO}_{2}$ exposed animals remained in a somewhat more active state than those under normocapnia. 
Extrapolating from the discussion above small increments in $\mathrm{CO}_{2}$ may prevent early metabolic depression during warming.

The question arises how mild hypercapnia in M. edulis can prevent metabolic depression and thereby support tolerance to extreme warming. Other studies in fact report a $\mathrm{CO}_{2}$ dependent stimulation of mechanisms strengthening resilience. For example, hypercapnia reportedly induces a release of adenosine into the haemolymph of crustaceans and thereby stimulates cardiac performance (e.g. Stegen and Grieshaber, 2001). The fact that heart rate did not increase indicates that this hypothesis does not apply to the blue mussel (see Fig. 6). Findings in mammals show that $\mathrm{CO}_{2}$ can stimulate neuronal function (Dulla et al., 2005). There are no such findings reported for mussels, leaving the exact mechanism behind putative $\mathrm{CO}_{2}$ induced metabolic stimulation obscure.

The results of the present study imply that the circulatory system of M. edulis reached its temperature-induced capacity limit above $25^{\circ} \mathrm{C}$ in both groups, indicating the onset of the pejus range at this temperature. The $\mathrm{T}_{\mathrm{C}}$ of $M$. edulis was also unaffected by moderate hypercapnia and found above $28{ }^{\circ} \mathrm{C}$ when succinate concentration rose sharply and regardless of $\mathrm{CO}_{2}$ treatment. In crustaceans, it could recently be shown that hypercapnia led to a downward shift of the upper critical tempera-

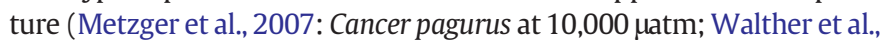
2009: Hyas araneus at 710 and $3000 \mu \mathrm{atm})$. No such shift could be observed in the present study, which might again be explained by the different habitats and pre-adaptation of Mytilus to life in the sub- and intertidal zone with highly fluctuating $\mathrm{CO}_{2}$ concentrations and temperatures. Similar to permanently submersed cephalopods and fish, crustaceans regulate their internal milieu rather well (for review, see Whiteley, 2011). A higher energetic effort in acid-base regulation may lead to thermal tolerance shifts responding more strongly to hypercapnia in crustaceans than in the bivalve.

Hypercapnic exposure caused a reduced haemolymph $\mathrm{pH}$ in M. edulis. The extracellular acidosis remained uncompensated despite some compensation visible in a significantly increased $\left[\mathrm{HCO}_{3}^{-}\right]$level. The same patterns were reported for other bivalves (Michaelidis et al., 2005; Lannig et al., 2010) and lower marine invertebrates (Pörtner et al., 1998).

Although no significant impact of increasing $\mathrm{CO}_{2}$ level was detected on haemolymph $\mathrm{PCO}_{2}$ (neither at acclimation temperature nor during warming), values were increased under hypercapnia at control temperature and match the ones found by Thomsen et al. (2010) under similar conditions. During warming, levels increased suddenly above $28^{\circ} \mathrm{C}$ at the critical temperatures in all treatments. Nevertheless, heat stress under normocapnia resulted in higher internal $\mathrm{CO}_{2}$ accumulation above $28^{\circ} \mathrm{C}$, due to acidosis and less gas exchange. A stronger respiratory acidosis in normocapnic animals was prevented by significant $\left[\mathrm{HCO}_{3}^{-}\right]$accumulation. This indicates potential use of residual acid-base regulation capacity under normocapnia, which was not available to hypercapnic mussels in the warmth. Future studies have to show whether metabolically depressed animals have the ability to sustain critical conditions longer than mussels e.g. under hypercapnia, when metabolic depression is prevented.

\section{Conclusion}

Overall, physiological transitions observed during warming of North Sea blue mussels M. edulis mirror the tolerance thresholds as defined by the OCLTT concept. The warming induced fall in haemolymph $\mathrm{pH}$ may be involved in setting the pejus temperature $\left(T_{P}\right.$, onset of falling aerobic scope) at $25{ }^{\circ} \mathrm{C}$ by dampening heart rate regardless of $\mathrm{CO}_{2}$ treatment. The critical temperature found above $28{ }^{\circ} \mathrm{C}\left(\mathrm{T}_{\mathrm{C}}\right.$, onset of anaerobic metabolism) also remained unaffected by moderate hypercapnia indicating that the population studied may be resilient to $\mathrm{CO}_{2}$ oscillations, possibly related to its pre-adaptation to life in the intertidal zone. While normocapnic mussels showed a somewhat earlier limitation in temperature-dependent oxygen consumption rate (breakpoint temperature $25.2^{\circ} \mathrm{C}$ ) and actively defended their internal milieu when reaching critical limits most hypercapnic mussels remained in an active state (breakpoint temperature $28.8^{\circ} \mathrm{C}$ ) and failed to significantly increase their haemolymph $\left[\mathrm{HCO}_{3}^{-}\right]$level in the warmth. Thus, $\mathrm{CO}_{2}$ exposure modulated the response to warming by somewhat reducing the degree of metabolic depression in the heat. It remains to be explored whether this effect is adaptive or reduces the capacity to sustain fitness in a highly variable environment. Especially during longer periods of exposure the latter may be harmful for sustained ecological performance of $M$. edulis.

\section{Author contributions}

Conceived and designed the experiments: ZMCZ and HOP.

Performed the experiments: ZMCZ, with the help of CB.

Analysed and interpreted the data: $\mathrm{ZMCZ}$, with the help of $\mathrm{HOP}, \mathrm{CB}$ and GL.

Contributed reagents/materials/analysis tools: ZMCZ, CB, and HOP.

Wrote the paper: ZMCZ, CB, and HOP.

Revision of the paper: ZMCZ, GL, and HOP.

\section{Acknowledgements}

This work is a contribution to the "European Project on Ocean Acidification" (EPOCA) which received funding from the European Community's Seventh Framework Programme (FP7/2007-2013) under grant agreement no 211384. EPOCA is endorsed by the International Programmes IMBER, LOICZ and SOLAS. This project was also supported by the Helmholtz Graduate School for Polar and Marine Research (POLMAR). The authors would like to thank Stephan Frickenhaus for statistical support. [SES]

\section{References}

Barton, A., Hales, B., Waldbusser, G.G., Langdon, C., Feely, R., 2012. The pacific oyster Crassostrea gigas, shows negative correlation to naturally elevated carbon dioxide levels: implications for near-term ocean acidification effects. Limnol. Oceanogr. 57 (3), 698-710. http://dx.doi.org/10.4319/lo.2012.57.3.0698.

Bayne, B.L., Scullard, C., 1977. An apparent specific dynamic action in Mytilus edulis L. J. Mar. Biol. Assoc. UK 57, 371-378.

Bayne, B.L., Thompson, R.J., Widdows, J., 1973. Some effects of temperature and food on the rate of oxygen consumption by Mytilus edulis. In: Wieser, W. (Ed.), Effects of Temperature on Ectothermic Organisms. Springer, Berlin and Heidelberg, pp. 181-193.

Berge, J.A., Bjerkeng, B., Pettersen, O., Schanng, M.T., Oxnevad, S., 2006. Effects of increased sea water concentrations of $\mathrm{CO}_{2}$ on growth of the bivalve Mytilus edulis $\mathrm{L}$. Chemosphere 62, 681-687.

Booth, C.H., McDonald, D.G., Walsh, P.J., 1984. Acid-base balance in the sea mussel, Mytilus edulis. I. Effects of hypoxia and air-exposure on hemolymph acid-base status. Mar. Biol. Lett. 5, 347-358.

Braby, C.E., Somero, G.N., 2006. Following the heart: temperature and salinity effects on heart rate in native and invasive species of the blue mussels (genus Mytilus). J. Exp. Biol. 209, 2554-2566.

Connor, K.M., Gracey, A.Y., 2012. High-resolution analysis of metabolic cycles in the intertidal mussel Mytilus californianus. Am. J. Physiol. Regul. Integr. Comp. Physiol. 302, R103-R111. http://dx.doi.org/10.1152/ajpregu.00453.2011.

Davenport, J., Smith, R.J.J.W., Packer, M., 2000. Mussels Mytilus edulis: significant consumers and destroyers of mesozooplankton. Mar. Ecol. Prog. Ser. 198, 131-137.

Dejours, P., 1975. Principles of Comparative Respiratory Physiology. Elsevier, New York.

Dickson, A.G., 1990. Thermodynamics of the dissociation of boric-acid in potassiumchloride solutions form $273.15 \mathrm{~K}$ to $318.15 \mathrm{~K}$. J. Chem. Thermodyn. 22, 113-127.

Dickson, A.G., Millero, F.J., 1987. A comparison of the equilibrium constants for the dissociation of carbonic acid in seawater media. Deep-Sea Res. 34 (111), 1733-1743.

Doney, S.C., Fabry, V.J., Feely, R.A., Kleypas, J.A., 2009. Ocean acidification: the other $\mathrm{CO}_{2}$ problem. Ann. Rev. Mar. Sci. 1, 169-192.

Dulla, C.G., Dobelis, P., Pearson, T., Frenguelli, B.G., Staley, K.J., Masino, S.A., 2005 Adenosine and ATP link P- $\mathrm{CO}_{2}$ to cortical excitability via pH. Neuron 48, 1011-1023. http://dx.doi.org/10.1016/j.neuron.2005.11.009.

Fabry, V.J., Seibel, B.A., Feely, R.A., Orr, J.C., 2008. Impacts of ocean acidification on marine fauna and ecosystem processes. ICES J. Mar. Sci. 65, 414-432.

Fernández-Reiriz, M.J., Range, P., Álvarez-Salgado, X.A., Labarta, U., 2011. Physiological energetics of juvenile clams Ruditapes decussatus in a high $\mathrm{CO}_{2}$ coastal ocean. Mar. Ecol. Prog. Ser. 433, 97-105. http://dx.doi.org/10.3354/meps09062.

Fernández-Reiriz, M.J., Range, P., Álvarez-Salgado, X.A., Espinosa, J., Labarta, U., 2012. Tolerance of juvenile Mytilus galloprovincialis to experimental seawater acidification. Mar. Ecol. Prog. Ser. 454, 65-74. http://dx.doi.org/10.3354/meps09660. 
Frederich, M., Pörtner, H.O., 2000. Oxygen limitation of thermal tolerance defined by cardiac and ventilatory performance in spider crab, Maja squinado. Am. J. Physiol. Regul. Integr. Comp. Physiol. 279, R1531-R1538.

Gaffney, P.M., Diehl, W.J., 1986. Growth, condition and specific dynamic action in the mussel Mytilus edulis recovering from starvation. Mar. Biol. 93, 401-409.

Gazeau, F., Alliouane, S., Bock, C., Bramanti, L., López Correa, M., Gentile, M., Hirse, T., Pörtner, H.O., Ziveri, P., 2014. Impact of ocean acidification and warming on the Mediterranean mussel (Mytilus galloprovincialis). Front. Mar. Sci. 1, 62. http://dx.doi.org/ 10.3389/fmars.2014.00062.

Guppy, M., Fuery, C.J., Flanigan, J.E., 1994. Biochemical principles of metabolic depression. Comp. Biochem. Physiol. B Biochem. Mol. Biol. 1098 (23), 175-189.

Heisler, N., 1986. Buffering and transmembrane ion transfer processes. In: Heisler, N. (Ed.), Acid-Base Regulation in Animals. Elsevier, Amsterdam, pp. 3-47.

Hines, A., Oladiran, G.S., Bingell, J.P., Stentiford, G.D., Viant, M.R., 2007. Direct sampling of organisms from the field and knowledge of their phenotype: key recommendations for environmental metabolomics. Environ. Sci. Technol. 41, 3375-3381.

Kroeker, K.J., Kordas, R.L., Crim, R.N., Singh, G.G., 2010. Meta-analysis reveals negative yet variable effects of ocean acidification on marine organisms. Ecol. Lett. 13, 1419-1434.

Langenbuch, M., Pörtner, H.O., 2002. Changes in metabolic rate and N excretion in the marine invertebrate Sipunculus nudus under conditions of environmental hypercapnia: identifying effective acid-base variables. J. Exp. Biol. 205, 1153-1160.

Lannig G., Bock, C. Sartoris, FJ., Pörtner, H.O., 2004. Oxygen limitation of therma tolerance in cod, Gadus morhua L., studied by magnetic resonance imaging and online venous oxygen monitoring. Am. J. Physiol. Regul. Integr. Comp. Physiol. 287, R902-R910. http://dx.doi.org/10.1152/ajpregu.00700.2003.

Lannig, G., Eilers, S., Pörtner, H.O., Sokolova, I.M., Bock, C., 2010. Impact of ocean acidification on energy metabolism of oyster, Crassostrea gigas-changes in metabolic pathways and thermal response. Mar. Drugs 8, 2318-2339. http://dx.doi.org/10.3390/ md8082318.

Lindinger, M., Lauren, D., McDonald, D., 1984. Acid-base balance in the sea mussel, Mytilus edulis. III Effects of environmental hypercapnia on intra- and extracellular acid-base balance. Mar. Biol. Lett. 5, 371-381.

Liu, W., He, M., 2012. Effects of ocean acidification on the metabolic rates of three species of bivalve from southern coast of China. Chin. J. Oceanol. Limnol. 30 (2), 206-211. http://dx.doi.org/10.1007/s00343-012-1067-1.

Lundebye, A.K., Langston, W.J., Depledge, M.H., 1997. Stress proteins and condition index as biomarkers of TBT exposure. Ecotoxology 6, 127-136.

Mark, F.C., 2001. Sauerstoffabhängigkeit der Temperaturtoleranz bei marinen Fischen? (Diploma thesis) University of Bremen, Germany

Mehrbach, C., Culberson, C.H., Hawley, J.E., Pytkowicz, R.M., 1973. Measurement of the apparent dissociation constants of carbonic acid in seawater at atmospheric pressure. Limnol. Oceanogr. 18 (6), 897-907.

Melzner, F., 2005. Systemphysiologische Untersuchungen zur Temperaturtoleranz des gemeinen Tintenfischs (Sepia officinalis) ( $\mathrm{PhD}$ thesis) University of Bremen, Germany.

Melzner, F., Bock, C., Pörtner, H.O., 2006. Temperature-dependent oxygen extraction from the ventilatory current and the costs of ventilation in the cephalopod Sepia officinalis. J. Comp. Physiol. B. 176 (7), 607-621.

Melzner, F., Gutowska, M.A., Langenbuch, M., Dupont, S., Lucassen, M., Thorndyke, M.C. Bleich, M., Pörtner, H.O., 2009. Physiological basis for high $\mathrm{CO}_{2}$ tolerance in marine ec tothermic animals: pre-adaptation through lifestyle and ontogeny? Biogeosciences 6 2313-2331.

Melzner, F., Stange, P., Trübenbach, K., Thomsen, J., Casties, I., Panknin, U., Gorb, S.N., Gutowska, M.A. 2011. Food supply and seawater pCO2 impact calcification and internal shell dissolution in the blue mussel Mytilus edulis. PLoS One 6, e24223.

Metzger, R., Sartoris, F., Langenbuch, M., Pörtner, H.O., 2007. Influence of elevated $\mathrm{CO}_{2}$ concentrations on thermal tolerance of the edible crab Cancer pagurus. J. Therm. Biol. 32 (3), 144-151. http://dx.doi.org/10.1016/j.jtherbio.2007.01.010.

Michaelidis, B., Ouzounis, C., Paleras, A., Pörtner, H.O., 2005. Effects of long-term moderate hypercapnia on acid-base balance and growth rate in marine mussels Mytilus galloprovincialis. Mar. Ecol. Prog. Ser. 293, 109-118.

Noack, S., 1980. Statistische Auswertung von Meß- und Versuchsdaten mit Taschenrechner und Tischcomputer. Walter de Gruyter, Berlin, New York, pp. 373-382.

Okumus, I., Stirling, H.P., 1994. Physiological energetics of cultivated mussel (Mytilus edulis) populations in 2 Scottish west-coast sea lochs. Mar. Biol. 119 (125-131), 1994

Parker, L.M., Ross, P.M., O'Connor, W.A., Pörtner, H.O., Scanes, E., Wright, J.M., 2013. Predicting the response of molluscs to the impact of ocean acidification. Biology 2 , 651-692. http://dx.doi.org/10.3390/biology2020651.

Peck, L.S., Pörtner, H.O., Hardewig, I., 2002. Metabolic demand, oxygen supply and critical temperatures in the Antarctic bivalve Laternula elliptica. Physiol. Biochem. Zool. 75 $123-133$.

Pierrot, D., Lewis, E., Wallace, D.W.R., 2006. CO2SYS DOS Program Developed for $\mathrm{CO}_{2}$ System Calculations, ORNL/ CDIAC-105. Carbon Dioxide Information Analysis Center, Oak Ridge National Laboratory, US Department of Energy, Oak Ridge.

Poloczanska, E.S., Hoegh-Guldberg, O., Cheung, W., Pörtner, H.-O., Burrows, M., 2014 Cross-chapter box on observed global responses of marine biogeography, abundance and phenology to climate change. In: Field, C.B., Barros, V.R., Dokken, D.J., K.J. (Eds.), Climate Change 2014: Impacts, Adaptation, and Vulnerability. Part A: Global and
Sectoral Aspects. Contribution of Working Group II to the Fifth Assessment Report of the Intergovernmental Panel on Climate Change. Cambridge University Press, Cambridge, United Kingdom and New York, NY, USA, pp. 123-127.

Pörtner, H.O., 2001. Climate change and temperature-dependent biogeography: oxygen limitation of thermal tolerance in animals. Naturwissenschaften 88, 137-146. http://dx.doi.org/10.1007/s001140100216.

Pörtner, H.O., 2008. Ecosystem effects of ocean acidification in times of ocean warming: a physiologist's view. Mar. Ecol. Prog. Ser. 373, 203-217.

Pörtner, H.O., 2010. Oxygen- and capacity-limitation of thermal tolerance: a matrix for integrating climate-related stressor effects in marine ecosystems. J. Exp. Biol. 213, 881-893. http://dx.doi.org/10.1242/jeb.037523.

Pörtner, H.O., Reipschlager, A., Heisler, N., 1998. Acid-base regulation, metabolism and energetics in Sipunculus nudus as a function of ambient carbon dioxide level. J. Exp. Biol. 201, 43-55.

Pörtner, H.O., Karl, D.M., Boyd, P.W., Cheung, W.W.L., Lluch-Cota, S.E., Nojiri, Y., Schmidt, D.N., Zavialov, P.O., 2014. Ocean systems. In: Field, C.B., Barros, V.R., Dokken, D.J., K.J. (Eds.), Climate Change 2014: Impacts, Adaptation, and Vulnerability. Part A: Global and Sectoral Aspects. Contribution of Working Group II to the Fifth Assessment Report of the Intergovernmental Panel on Climate Change. Cambridge University Press, Cambridge, United Kingdom and New York, NY, USA, pp. 411-484.

Reipschläger, A., Pörtner, H.O., 1996. Metabolic depression during environmental stress: the role of extracellular versus intracellular pH in Sipunculus nudus. J. Exp. Biol. 199, 1801-1807.

Schalkhausser, B., Bock, C., Stemmer, K., Brey, T., Pörtner, H.O., Lannig, G., 2012. Impact of ocean acidification on escape performance of the king scallop, Pecten maximus, from Norway. Mar. Biol. http://dx.doi.org/10.1007/s00227-012-2057-8.

Schlüter, L., Johansen, S.B., 1994. Annual variation in condition, respiration and remineralisation of Mytilus edulis L. in the Sound, Denmark. Helgoländer Meeresun. $48,419-430$

Sokal, R.R., Rohlf, F.J., 1995. Biometry. W. H. Freeman \& Co., New York

Stegen, E., Grieshaber, M.K., 2001. Adenosine increases ventilation rate, cardiac performance and haemolymph velocity in the American lobster Homarus americanus. J. Exp. Biol. 204, 947-957.

Sukhotin, A.A., Pörtner, H.O., 1999. Habitat as a factor involved in the physiological response to environmental anaerobiosis of White Sea Mytilus edulis. Mar. Ecol. Prog. Ser. $184,149-160$.

Sukhotin, A.A., Pörtner, H.O., 2001. Age-dependence of metabolism in mussels Mytilus edulis (L.) from the White Sea. J. Exp. Biol. Ecol. 257, 53-72

Thomas, H., Prowe, A.E.F., van Heuven, S., Bozec, Y., de Baar, H.J.W., Schiettecatte, L.-S., Suykens, K., Koné, M., Borges, A.V., Lima, I.D., Doney, S.C., 2007. Rapid decline of the $\mathrm{CO}_{2}$ buffering capacity in the North Sea and implications for the North Atlantic Ocean. Glob. Biogeochem. Cycles 21, GB4001. http://dx.doi.org/10.1029/ 2006GB002825.

Thomsen, J., Melzner, F., 2010. Moderate seawater acidification does not elicit long-term metabolic depression in the blue mussel Mytilus edulis. Mar. Biol. 157, 2667-2676. http://dx.doi.org/10.1007/s00227-010-1527-0.

Thomsen, J., Gutowska, M.A., Saphörster, J., Heinemann, A., Trübenbach, K., Fietzke, J., Hiebenthal, C., Eisenhauer, A., Körtzinger, A., Wahl, M., Melzner, F., 2010. Calcifying invertebrates succeed in a naturally $\mathrm{CO}_{2}$ enriched coastal habitat but are threatened by high levels of future acidification. Biogeosci. Discuss. 7, 5119-5156. http://dx.doi. org/10.5194/bgd-7-5119-2010.

Van Dijk, P.L.M., Tesch, C., Hardewig, I., Pörtner, H.O., 1999. Physiological disturbances at critically high temperatures: a comparison between stenothermal antarctic and eurythermal temperate eelpouts (Zoracidae). J. Exp. Biol. 202, 3611-3621.

Walsh, P.J., McDonald, D.G., Booth, C.H., 1984. Acid-base balance in the sea mussel, Mytilus edulis. II. Effects of hypoxia and air-exposure on intracellular acid-base status. Mar. Biol. Lett. 5, 359-369.

Walther, K., Sartoris, F.J., Bock, C., Pörtner, H.O., 2009. Impact of anthropogenic ocean acidification on thermal tolerance of the spider crab Hyas araneus. Biogeosciences 6, 2207-2215.

Whiteley, N.M., 2011. Physiological and ecological responses of crustaceans to ocean acidification. Mar. Ecol. Prog. Ser. 430, 257-271. http://dx.doi.org/10.3354/meps09185.

Widdows, J., 1973a. The effects of temperature on the metabolism and activity of Mytilus edulis. Neth. J. Sea Res. 7, 387-398.

Widdows, J., 1973b. Effect of temperature and food on the heart beat, ventilation and oxygen uptake of Mytilus edulis. Mar. Biol. 20, 269-276.

Widdows, J., 1976. Physiological adaptation of Mytilus edulis to cyclic temperatures. J. Comp. Physiol. 105, 115-128.

Zittier, Z.M.C., Hirse, T., Pörtner, H.O., 2013. The synergistic effects of increasing temperature and $\mathrm{CO}_{2}$ levels on activity capacity and acid-base balance in the spider crab, Hyas araneus. Mar. Biol. 160 (8), 2049-2062. http://dx.doi.org/10.1007/s00227-012-2073-8.

Zittier, Z.M.C., Bock, C., Sukhotin, A.A., Hafka, S., Pörtner, H.O., 2015. Impact of ocean acidification on thermal tolerance and acid-base regulation of Mytilus edulis from the White Sea (in prep.).

Zurburg, W., Kluytmans, J.H., 1980. Organ specific changes in energy metabolism due to anaerobiosis in the sea mussel Mytilus edulis (L.). Comp. Biochem. Physiol. 67, B, 317-B, 322. 